\title{
AN X-RAY LAMINOGRAPHIC STUDY OF ADENOID
}

\author{
HIROSHI MURAMATSU, M.D. \\ Department of Oto-Rhino-Laryngology, Yokohama City University, \\ School of Medicine (Director : T. Kashiwado, M.D.)
}

The diagnosis of adenoid vegetation is made by anterior and posterior rhinoscopy or manual palpation as the routine procedure, but precise findings of the adenoids can scarcely be obtained by these methods. From these reasons various roentgenographic examinations are now applied for supplement.

But the application of X-ray-laminographic methods are not yet thoroughly studied. Therefore the author has tried to use the laminogram for the diagnosis of adenoid vegetation, examining detailed techniques and analysing the findings.

In the first step, the $\mathrm{X}$-ray exposure factors, the direction of the exposure, the position of the head and body, and the status of respiration on exposure were analysed to obtain the most suitable pictures of adenoids. And it was found that the most important mathers among the various exposure factors was the angle of the tube movement. The best pictures were taken by a wide angle of 50 degrees. As for the position of the head and body, only by the midline sagittal laminogram with the patient in prone position, twisting his head ninety degrees so that the midline sagittal plane of the head became parallel to the film. Frontal, oblique and other views yielded no satisfactory visualization of the adenoids. As to the status of respiration, nasal respiration at rest was found to be optimal for the laminography.

In the 2nd step, the change between the laminograms before and after tonsillectomy were investigated by measuring decreased area of the shadow of the tonsils, which were compared with the weight and volume of the cut out piece of the tonsil. And it was affirmed that the finding of the tonsil in the lamino. gram showed an exact shadow of the tonsil.

At last, the author designed and produced a sort of fixing implement of the head for the laminography, which was very convenient and useful.

As the conclusion, the author wishes to recommend the midline sagittal laminogram of the head for the evaluation of the status of the pharyngeal tonsil.

\section{咽頭扁桃の断層 $\mathrm{X}$ 線学的研究}

\author{
横捠市立大学医学部耳鼻咽喹科学教室 (主任：柏戸貞一教骎)

$$
\text { 研究生村松弘 弘 }
$$

\section{目次}

粕 論

第 1 編 正中矢状面断層 X線撮影法水関寸る研先

1. 艘票

2. 研究方法

3. 研笑成縝

4. 総括並び考按

5. 結 語

第 2 漏 フデノトミ一前後の断層X線像に関する研究

1: 粕 言
2. 研究方法

3. 研究成跬

4. 総括並びに考按

5. 結 語

第 3 編 頭部固定法阔する開究（頭部 X線振影固定器 の試作)

1. 緒言

2. 研究方法

3. 研究成繢

4. 総括並びに考按 
$70-1652$

$$
\text { 5. 結 語 }
$$

主要参考文献

\section{緒論}

1868年 Kopenhagen の耳鼻科医，Wilhelm Meyer が

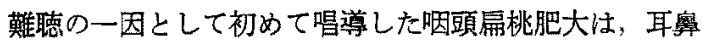
咽㮢科領域における小児の主要疾患の一で, 周囲器官に 対し種々の障害を及活し，殊に耳卑の各疾患を併発ある いは増覀させることが多い。れに対しその診断には，

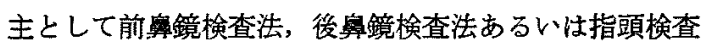
法等が慣用されている。しかし，検查の対象となるもの は，幼小先が多いため，検查に対する抵抗が強いこと やあるいは同時に存在することの多い粺・咽頭の分必 物や奥甲介・口蓋扁桃の肥大等のため，これらの検查法 のみにより咽頭扁桃の正確な所見を把握することは甚だ 困難である、これがため上記諸検查法以外に今日におい てはX線撮影も補助診断法としてかなり重視されるよ5 になり，単純撮影法，高電死撮影法，造影斉熶影法等が 報告されるに至った。しかしこれらの方法についても， 骨の重複像やコントラスト不足のため，また高電圧X線 発生装置の必要性, あるいはまた造影風使用という患者 に与える不快や面倒などのため更に一勫有効な方法が要 望されている状態である:

これに対し近年は断層 $\mathrm{X}$ 線撮影法も耳鼻咽喉科領域に おいて聴器, 鼻・副鬼腔あるいは喉頭の洗患の診断に広 く利用され，可なりの効果をあげるに至っている，その 理由は面倒な造影凧の使用を避け，かつまた従来行なわ れて来た平面的撮影法の久陷を解決することができるた めである。これらの点より断層X線撮影法は咽頭屚挑の X楾写真撮影に好適ではないかと考えられる。しかし文 献的にはこの種の研究が見当らない．よって今回，咽頭 嵋桃診断に断層 X線撮影法を応用することを研究したの でここに報告する。なお本研究においては断層X線振影 を断層撮影と略記することとする。

\section{第 1 編 正中矢状面断層 $\mathbf{X}$ 線撮影法 に関する研究}

\section{1. 踷言}

咽頭屌䄻のX線診断において，断層撮影を応用するに 至った動機を更に詳しく文献的考察を加えて記すれば次 のようである.

1)单純撮影その他

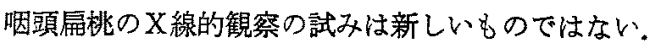

Röntgen 線の発見後をむない1898年, Mignon ${ }^{11}$ にっっ て始めて，X線透視により胭頭屜桃を認め得ると報告さ れた，その後，単純撮影については，Grandy2) (1925) が手術前後の症例を観察し, X線写真が手術時の指標上 なることを述べた. Schüller"（1929）は咽頭扁桃疾患に X線猃断法の利用を試みた。 Székács-Friedmann ${ }^{4)}$ (19 32）は咽頭扁桃について夢科的検査法とX線像の比較を 行ない，臨床診断とX線診断法との判定の結果は $90 \%$ に 一致すると述べ，更に正常人の奥咽腔の形態について論 した．また Groth ${ }^{5)}$ (1933) はX線診断法は患者に不快 感を与えることがないので, 従来慣用されて来た指頭検 㚗法に代わる心゙きものであると論じ，X線写真の重要性 を指摘した．更にCalthrop ${ }^{6)}$ (1940) はX線写真につい て手術後の咽頭屚桃の再生状態を調べた。 Weit $z^{7)}$ (19 46), Bjuggren 等 ${ }^{8}$ (1952) はX線写真により咽頭扁挑 肥大度の分類を試み，Zwiefach" (1954) は小児の口呼 吸の原因をX線的に観察し，正しく評価された㸶頭扁姚 のX線写真は，常に外科的所見と一致することを報告し た. Wilson ${ }^{10)}$ (1955) は補助的診断法としての価值を 述へた。，以上のように多くの報告がなされ，いずれも 線の診断的応用価値を高く評洒している。しかしこれ らは皆軟線撮影による低電圧, 大電流方式の撮影法であ り，胭頭扁聎像は下䓏骨の影に奶げられ明瞭な輪敦を得 ることは難しいと考えられる。またこれらはいずれも補 助的診断法であると述べているにすぎない。

2) 造影剂撮影法

造影剂を使用する撮影法としては，Groth ${ }^{5 !}$ (1933)， Zuppinger \& Rüedi ${ }^{111}$ (1934), 大藤 ${ }^{22)}$ (1935) : Lipiodol, Moulinard ${ }^{13)}$ (1949) : 35\% Oparenol + 25\% Sub. tosan, 神 ${ }^{14)}$ (1954) : Ba 粉末, 渡部 ${ }^{15)}$ (1956) :33\% Sugiuron 液, 飯田 ${ }^{16)}$ (1959)：油性ウロコリン, 後藤 ${ }^{17}$

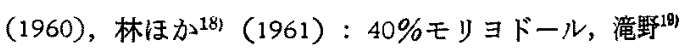
(1962) : エンドグラフィン, Jing 他 ${ }^{20)}$ (1965)：Oily Dionosil 等の記載があるが，多くは断片的なものであっ た，鼻咽腔造影法の多くは鼻咽膑の腫煌を目的としたも ので，同時に咽頭扁挑をも造影されると報告している， しかし鼻咽腔造影法は面倒な造影処置が必要であり，ま た不快感を与える点で小児の㸶頭扁桃の䚈察には不適当 であると考えられる。

\section{3）高電圧撮影法}

高電玨撮影法については30年前から多くの研究者の実 験報告があり，すぐれた特色を持つことが認められてい た. 戸塚ら ${ }^{21)}$ (1957) は㸶頭扁桃の肥大度を明膫に知る 
ことができると述べ，小泉ら"21（1958）は高電圧側位撮 影法により咽頭扁桃の全貌をほぼ正確に把握することが でき，幼小児における咽頭嵋桃疾患の診断, 経過観察, 記録等の一方法として利用できると述べた。 またアデ， トミ一前後のX線像と手術所見とを比較し，これを基に 洇頭扁桃肥大度のX線的分類を試み，更に鼻胭腔の形態 について諭じた。 その他, 滝戸23) (1956), 菱山他"21) (19 59), 日根95) (1959), 後藤 ${ }^{27}$ (1960), 伊藤 ${ }^{(6) 271}$ (1961), 岩沢 ${ }^{28)}$ (1965), 野辺地尔（1965） らの研究があり何れ も高電圧撮影法がアブノイド撮影に適していると報告し t.

\section{4） X線映画撮影法}

そこでX-Ray Image Intensity Amplifier を利用した 高電圧X線映画撮影法が耳奥咽喉科領域特に構音機構や 摭下運動の研究に上り入れられ，多くの報告がなされて

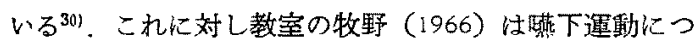
いて研究し, その中で咽頭扁桃も確認できると述べてい る.

\section{5）断層撮影法}

以上の研究に対し Bocage (1921) が断層撮影を最初

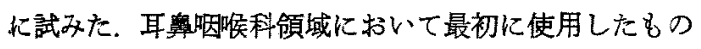
恃Vallebona (1930) であったが，その後1935年 Grossmann ${ }^{311}$, Chaoul らはこれを Tomograph と呼んで臨床 的に応用するに至った，以来断層撮影は主として頭部， 咽喉, 胸部において研究が行なわれ，その部の疾患の診 断法として広く利用されている。教室の三島 ${ }^{32)}$ (1959) 恃聴器疾患の診断に, ま寺田 ${ }^{33)}$ (1961) は楀腔の形態 に関して断層X線学的研究を報告した，その他語音発声 時の附属管腔の形態的変化と運動状況の観察に利用した 研究の報告も見られ ${ }^{34)}$, 更に後藤 ${ }^{171}$ (1960) は鼻咽腔疾 患の診断に有力な所見を提供すると述心゙，また番咽腔覀 性腫瑝の診断に断層熶影を利用したものとしては， Epstein $^{35)}$ (1951)，高須賀(他 ${ }^{36)}$ (1957)，金子 ${ }^{37)}$ (1961) の報告等多く見られるが，胭頭扁桃疾患の診断に試みた 報告はなされていない.

2. 研笢方法

i) 研究対象

藤技市立志太総合病院看護婦, 準看護婦羡生所生徒招 よぴアデノイド症状を呈する同病院耳則咽喉科外来患児 定対象とした。

ii）撮影装置並びに撮影条件の検討

a）提影装㯰：東芝截面撮影装固A-2型（円奶 移動式)
b）管球：東芝SDO-6-3型，焦点 $3 \times 3 \mathrm{~mm}^{2}$

c) 增感紙：極光 FS

d) 散乱線除去: Bucky Blende 使用

e) フィルム：富士XレイフィルムPX(八切)

f) 管電天：65 75kvp

g）管電流：30 40 mA

h) 回檕角度: $30^{\circ}, 40^{\circ}, 50^{\circ}$

i) 嚗射時䦓: $2 \sim 3$ 秒

j）焦点・断面間距㕍 : $100 \mathrm{~cm}$

k) 断面・フィルム間距雕 : 18〜20 cm

以上管電圧, 管電流, 回転角度, 曝射時間については 上記の諸条件の間で色々変えて撮影した。

iii）撮影断畨面の検討

胭頭扁桃切万頭部の前額面, 斜面, 矢状面等実用化 され得ると思われる各稫の截面で撮影し比較検討した。

iv）撮影断層方向の検璟

管球移動力向に対して頭軸を平行むよび直角と变えて 撮影し比較検討した。

v）撮影時呼吸の検討

吸気時, 呼気時, 呼吸時, 呼吸停止時の 4 つの状態に ついて撮影を試み，比較桧討した。

vi）撮影時姿勢の検討

上記撮影方法により適宜変更し，最も安楽な姿勢をと らせた。

vii）頭部固定法その他の検討

断層撮影の場合，撮影時間が $2 \sim 3$ 秒と長いため頭部 の固定は非常に重要なことで，固定は完全でなければな らない，砂露，圧迫帯，固定器等色々使用し，固定完全 を期した。また撮影時は睡眠，発声，あくび，藏下等の 諸運動は加論一切禁止した。

3. 研究成績

i）撮影条件について

管電圧 $65 \sim 75 \mathrm{kvp}$, 管電流 $30 \sim 40 \mathrm{~mA}$, 回転角度 $30^{\circ}$, $40^{\circ} ， 50^{\circ}$, 曝射時間 $2 \sim 3$ 秒以上色々の条件で撮影した $\mathrm{X}$ 線写真についてその結果を比較したところ,そのうち で最も良好な影像を得たのは，管電圧 $75 \mathrm{kvp}$, 管電流 40 $\mathrm{mA}$, 回転角度 $50^{\circ}$, 曝射時間 2 秒の諸条件のものであ った.

ii）撮影断層面について

咽頭扁挑を切る頭部の a) 前額面, b) 斜面, c) 矢状 面，d）その他の各種の面で同一症例について撮影した. [第 1 図参照]

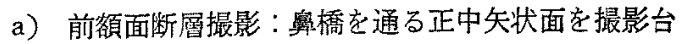


第 1 図撮影断層面説明

a) 前頞面断周撮影

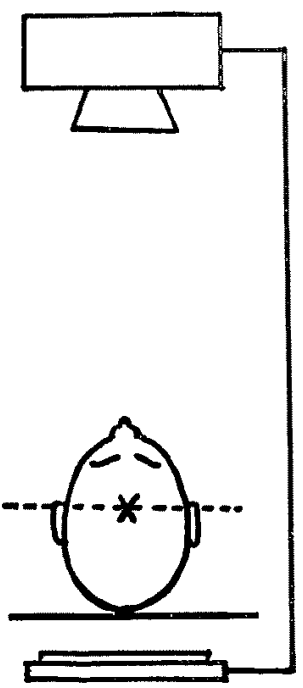

b) 斜面断圈衼影

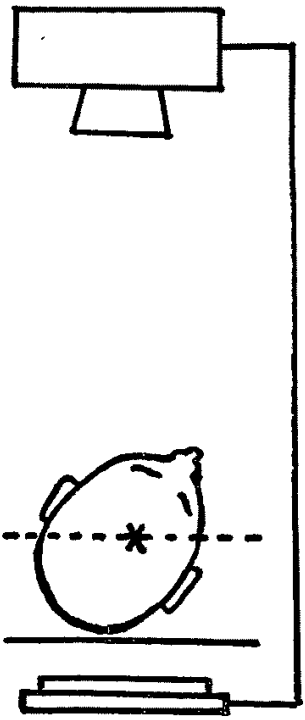

c) 失状面断曆撮影

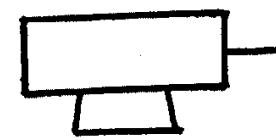

に直角とし，両側の外耳道口が同一高さ，かつまたドイ ツ水平面が撮影台に直危にした頭位の断痼撮影である。 この場合は，個人差により鼻失より鼻咽腔後壁すなわち 胭頭扁桃までの距離がまちまちであり，また因頭胍挑ま での確実な断層距離が得がたく従って断尿撮影により咽 頭扁桃を確実に把握することができず，X線写真像む不 明瞭で咽頭扁桃像堂明確に描出することはできなかっ た.

b）斜面断層撮影：前記の前額面撮影頭位より正中線 を中心にして頭部を適宜に回転して正中矢状面を撮影台 に傾科せしめたすのである。この場合も断層距離が決め 難く，X線写真像も最像が强く全く不明の結果京した.

c) 矢状面断勫撮影：ドイツ水平面を撮影台に直角と し，鼻橋を通る正中矢状面を撮影台に平行にした頭位 で，胭頭屚挑を正中矢状面にて断層撮影したものであ

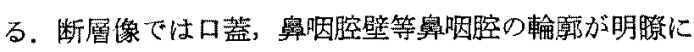
出現した。

d）その他の断層撮影：その他色々の截面で撮影した 結果，いずれも明膫な咽頭屚桃像を描写することはでき なかった。

以上の結果加らc）の正中矢状面断層撮影加最も良好 な結果を示すことを知った。

iii）撮影断層方向について
管球移動方向に対して頭軸を平行あるいは直角と色々 方向变変えて同一症例について撮影した，乙の模様は第 2 図に示す如くである。すなわち，

a）管球移動方向に対して頭軸を一致せしめ，管球を 頭嫄より足部へ回転した場合.

b）管球移動方向に対して頭軸を直角とし，管球を後 頭より前頭へ回転した場合.

両撮影法についての㧢頭屚桃断層像に関しては特に差 異を認めなかった。しかし装置および撮影台の構造上 a）の管球移動法が撮影操作上良好であった。

iv）撮影時呼吸について

撮影時の呼吸の状態に関しては，a）吸気時撮影の場 合は深い呼気に続いてゆっくり鼻より吸気させ，b) 呼 気時撮影の場合は逆に梁く吸気して少しう゚つ鼻より呼気 するように命じ，c）呼吸時撮影の場合は閉口して安静

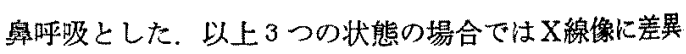
は缌められずこれらの場合はいずれも胭頭扁桃が明膫 に出現した。 これに対して，d）舟吸停止時撮影の場合 は軟口蓋が举上して奥咽腔を開鎖することが多く, 徒っ て㸶頭局桃像を不鮮明にした。

咽頭扁桃 X線像に対する呼吸時および呼吸停止時の措 影成績は第 1 表に示す通りであった。 寸なわち断層像が 明瞭に現われている場合を(H)，漠然と現われている場 
a) 頭軸々平行方向移動

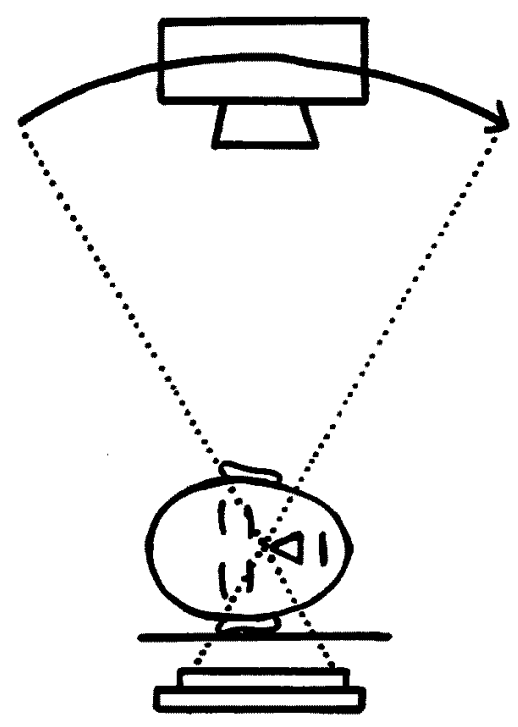

第 1 表 成人鼻咽腔飞対する呼吸時及び呼吸

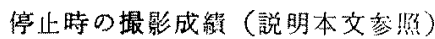

\begin{tabular}{|c|c|c|c|c|c|c|c|}
\hline \multirow[b]{2}{*}{ No. } & \multirow[b]{2}{*}{ 氏 名 } & \multirow{2}{*}{$\begin{array}{l}\text { 年令 } \\
\text { (才) }\end{array}$} & \multirow[b]{2}{*}{ 性 } & \multicolumn{2}{|c|}{ 呼 吸 時 } & \multicolumn{2}{|c|}{ 呼吸停止㭙 } \\
\hline & & & & 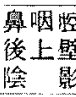 & $\begin{array}{c}\text { C口蒀 } \\
\text { 影 }\end{array}$ & $\begin{array}{l}\text { 學咽腔 } \\
\text { 後上壁 } \\
\text { 隍 }\end{array}$ & 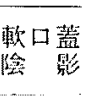 \\
\hline 1 & ○島○子 & 21 & $q$ & $H$ & $H$ & + & - \\
\hline 2 & O橋 $\bigcirc \supset$ & 21 & $q$ & $H$ & it & + & - \\
\hline 3 & ○遠○る & 21 & 9 & H & $H$ & + & + \\
\hline 4 & 青○と○ & 15 & q & $H$ & $H$ & + & + \\
\hline 5 & 石○聲○ & 15 & 우 & $H$ & H & + & + \\
\hline 6 & 芝○敬○ & 15 & 웅 & $H$ & $H$ & - & - \\
\hline 7 & 增 $\bigcirc$ 元 $\bigcirc$ & 15 & 우 & $H$ & $H$ & $H$ & + \\
\hline 8 & 塩 $\bigcirc$ 知 $\bigcirc$ & 15 & q & H & + & - & - \\
\hline 9 & 水○豊○ & 15 & 우 & $H$ & it & - & - \\
\hline
\end{tabular}

合を(十)，全く不明の場合を（一）とすると，呼吸時に おいては，鼻徆腔後上壁陰影は9例上もすぶて(H)で あり，軟口蓋陰影についても1例のみが（十で他はす ベて (H)であった。これに反して，呼吸停止の場合

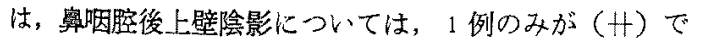
他は（十）が5例，(一)が3例であった。

v) 撮影時姿勢について

撮影装置並びに頭部の正中矢状面断層振影の関係上第

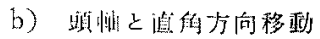

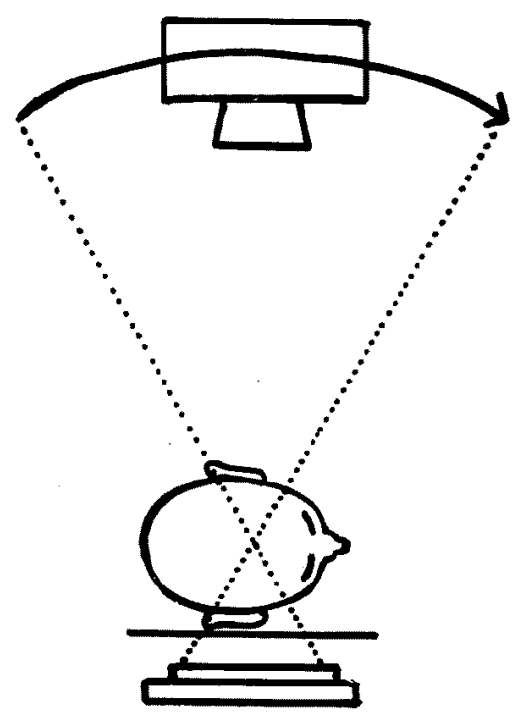

3 図に示すような姿勢が最良であった。すなわち呼吸を 楽にし，長時間頭部を固定せしめる必要上，最も安楽な 姿勢をとらせた，頭軸和よび体軸を管球移動方向に一致 せしめた体位にて, 右耳を下にして撮影台に密着し頭部 の正中知状面を撮影台に平行にして腹卧位をとらせ，続 いて左上半身を柽く起こし左手でこれを軽く支えた。こ の場合左上肢は撮影台と $30^{\circ}$ 位とし, 右上抆は体側につ けて台の上に置いた、更に下肢は雨側其伸展して楽にさ せた。

vi）頙部固定法その他について

固定器作製（第 3 編頭部固定法に関する研究にて後

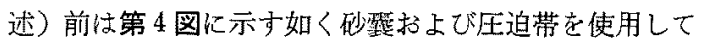
頭部を固定した。しかしこの固定法では不充分で，時に 撮影時被写体が動摇して撮影失敗することがあった。

vii）正中矢状面断首X楾撮影像について

以上i〜vi）にて述べた如く頭軸および体軸を管球移 動方向に一致せしめた腹犽位にて，頭部の正中矢状面を 撮影台に平行にした姿勢で，安静鼠呼吸時に断層方向を 下頑骨切痕部を中心として頭頂より足部への正中知状面 断層撮影が胭頭扁桃をX線写真上に最も解明かつ的確に 描写することができた，今７才男子の正中知面断層撮 影写真を示寸と第 5 図の如くである。気道腔とそれを囲

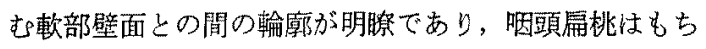



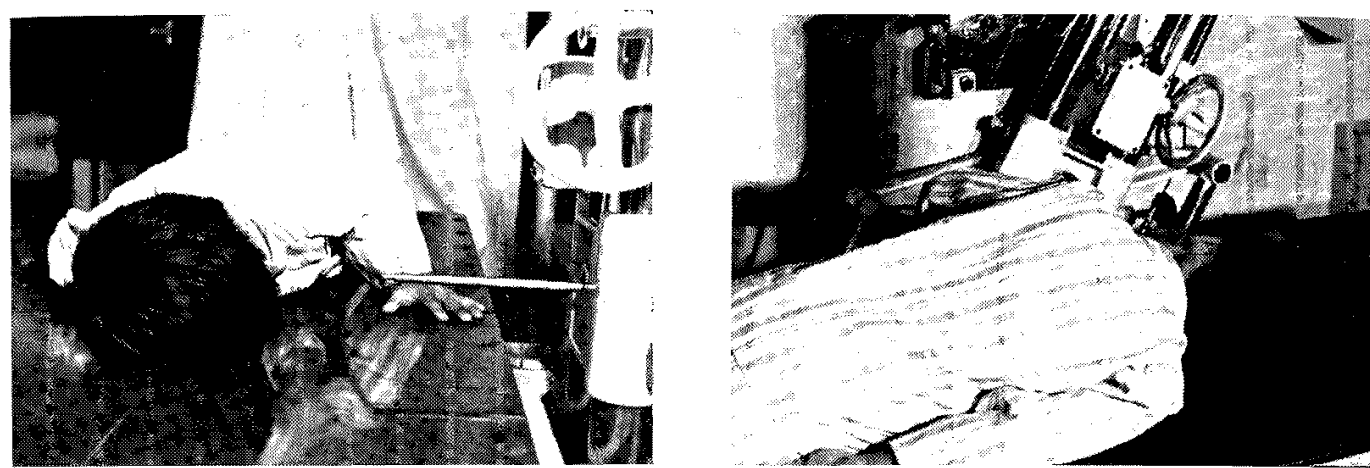

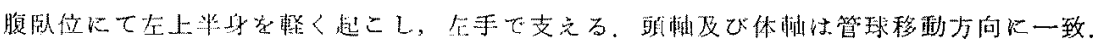
右耳を下にした䌿部の正中矢状圙は擬影台に平行。

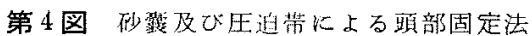

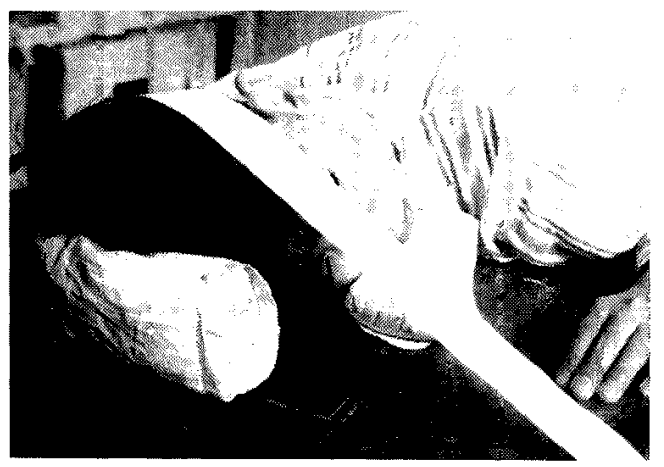

万ん下䀺常の影に防げられることなく，鼻胭腔後上壁よ

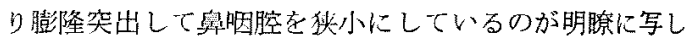
出されている。肥大せる咽頭叚桃の前後，上下の位置的 関係が植接わかり，具咽腔の広さ之胭頭屚桃の大きさ之

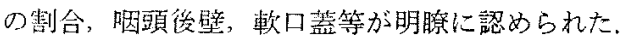

ここで20名の外来学垔患者に対して正中知状面断層撮

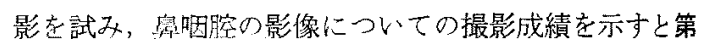
2 表の如くである。陰影の鮮明度を前述の $(H),(+)$, （一）で表わす上，奥咽腔後上壁（哂頭扁桃）陰影では （H）が17例，(十）が3例，(一)はなかった。亦た軟口

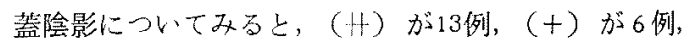
(一)が 1 例であった，なお本撮影例数红第 3 表の如く 2

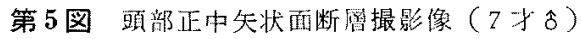
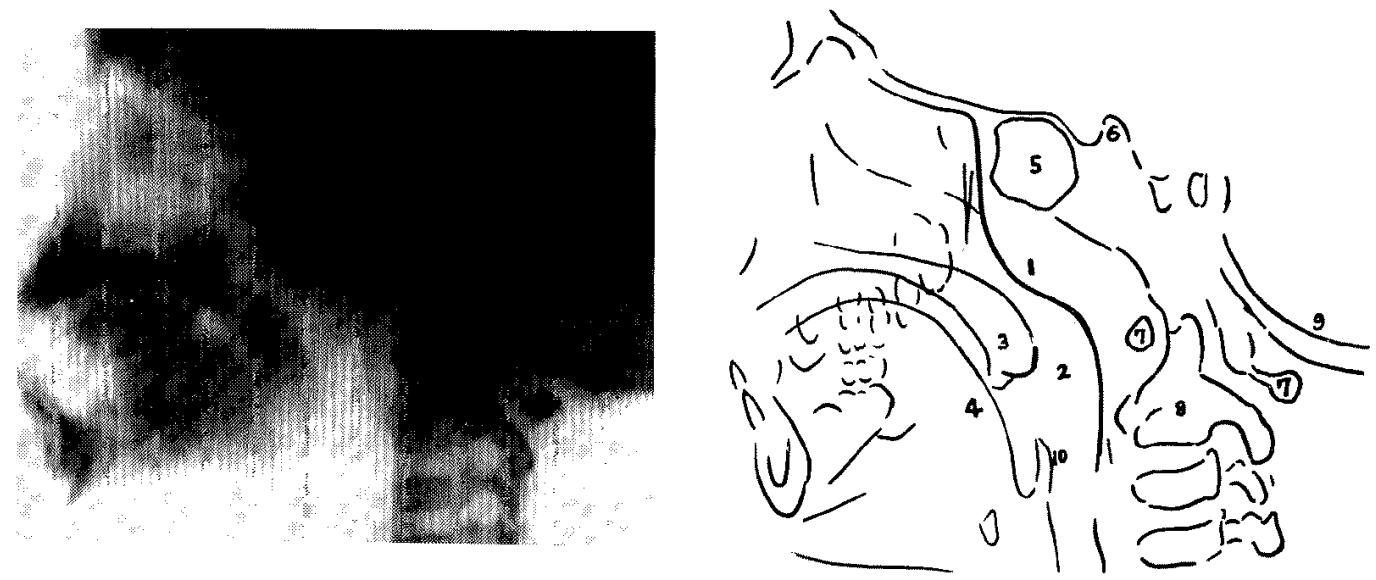

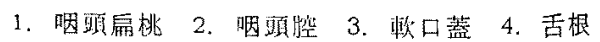

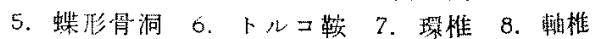

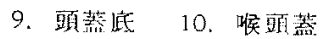


第2 表 外来学童患者の正中矢状面断䅉撮影成䋶

\begin{tabular}{|c|c|c|c|c|c|}
\hline No. & 氏 名 & 年令 & 性 & 咽頭扇桃陰影 & 軟口蓋陰影 \\
\hline 1 & 清 $\bigcirc$ 厚 $\bigcirc$ & $8 才$ & s & H & H \\
\hline 2 & 熊○秀O & 11 & $\hat{\delta}$ & \# & H \\
\hline 3 & 中O康 $\bigcirc$ & 6 & $q$ & H & + \\
\hline 4 & O本 0 & 9 & $\hat{o}$ & + & + \\
\hline 5 & 松○啓○ & 8 & ㅇ & H & H \\
\hline 6 & 河O正O & 14 & $\hat{o}$ & $H$ & H \\
\hline 7 & ○泉 $\bigcirc$ & 10 & $\delta$ & $H$ & $H$ \\
\hline 8 & ○沢○行 & 9 & $\hat{o}$ & H & + \\
\hline 9 & 川○淳○ & 8 & q & + & + \\
\hline 10 & ○田俊○ & 10 & 웅 & $H$ & $H$ \\
\hline 11 & ○田明 $\bigcirc$ & 10 & $q$ & $H$ & $H$ \\
\hline 12 & 手○春 $\bigcirc$ & 10 & $q$ & + & - \\
\hline 13 & 服 $\bigcirc$ 春子 & 10 & $q$ & $H$ & $H$ \\
\hline 14 & 松○○治 & 7 & $\hat{o}$ & H & + \\
\hline 15 & 作 $\bigcirc$ 春 $\bigcirc$ & 13 & $\hat{o}$ & $H$ & + \\
\hline 16 & 姅○正○ & 9 & $q$ & $H$ & $H$ \\
\hline 17 & 山○富子 & 9 & $q$ & H & H \\
\hline 18 & 山О甲О & 8 & $\delta$ & $H$ & $H$ \\
\hline 19 & 福○政○ & 11 & $\hat{o}$ & $H$ & $H$ \\
\hline 20 & ○崎 $\bigcirc \bigcirc$ & 8 & $\hat{o}$ & $H$ & $H$ \\
\hline
\end{tabular}

第 3 表 撮 影 例 数

\begin{tabular}{c|r|r|r}
\hline 年令 & \multicolumn{1}{|c|}{ o } & \multicolumn{1}{c|}{ o } & 計 \\
\hline \hline 2 才 & 2 & 1 & 3 \\
3 & 1 & 0 & 1 \\
4 & 2 & 4 & 6 \\
5 & 9 & 5 & 14 \\
6 & 18 & 20 & 38 \\
7 & 32 & 11 & 43 \\
8 & 18 & 21 & 39 \\
9 & 23 & 16 & 39 \\
10 & 10 & 7 & 17 \\
11 & 6 & 5 & 11 \\
12 & 4 & 2 & 6 \\
13 & 4 & 3 & 7 \\
14 & 6 & 6 & 12 \\
15 & 2 & 4 & 6 \\
\hline 計 & 137 & 105 & 242
\end{tabular}

才から15才まで 242 例である。

\section{4. 総括並びに考按}

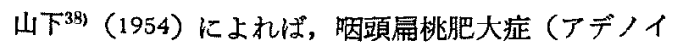

ド）の診断には，i）いわゆる諸アデノイド症状の碓諮，

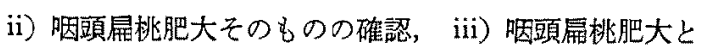
アデノイド症状との因果関係の推定が必要とされる。 こ れに対し咽頭扁挑肥大そのものの確認には299-67，i）前 鼻鏡検查, ii) 後奥鏡検查, iii）指頭検查, iv) 上咽頭 直達鏡検查 (Gyergyai 式, Yankauer 式あるいは久保式 等), v) 内視鏡检查 (nasal endoscope : Hirschmann \& Valentin 式, 永島式. post rhinoscope : Hay 式, Flatau 式, Treeck 式, 小野式), vi）中咽頭あるいは鼻腔 より綿棒を用いた触診と血液の附着具合による消息子唁 断. vii）鼠腔上りの穿刺針による検査 ${ }^{68}$ 等種々の方法が ある。しかしこれら諸法による確諗は奏際に注必ずしも 簡単ではない，これがためX線検査は非常に有効な補助 法と考えられる ${ }^{59}$ ( - 14). 今その方法について見るに，i） 透視法, ii）直接撮影法, iii）間接撮影法, iv）映画撮 影法等がある. 更にこれらは造影法と非造影法に分けら れる、これら諸法の優劣は緒言に記した通りである。こ れに対し一般臨床において容易に実施できる断層撮影活 -82)による咽頭扁桃の観察についてはこれまであまり充 分に研究されていない，よって著者は咽頭扁桃の断層撮 影について, 撮影条件, 撮影断層面, 撮影断層方向, 撮 影時呼吸，撮影姿勢等について検討した，検討に当って はそのX線写真の鮮鋭度および対照度が良好であること のために，先ず次の諸点を考虑した。

i）焦点の小さい管球を使用する.

ii）中心線のみを用いる.

iii）二次線を少なくするために遮光丹筒の細長いも のを用いる。

iv）焦点・被写体間距離をある程度遠くし，逆に被 写体・フィルム閒距離はできるだけ近かずける。

v）撮影時間を短かくする。

vi）被写体の姿勢を適切にして頭部の固定を確実に する。

vii）散乱線を充分に除く.

viii）高鮮鋭度の增感紙を使う。

このた放には種々比較実験の結果, 管電圧 $75 \mathrm{kvp}$, 管 電流 $40 \mathrm{~mA}$ ，嚗射時間 2 秒，焦点断面間距離 $100 \mathrm{~cm}$ が最 良の撮影条件であることを知った，更に回転角度につい ては次のよらに決定した。すなわち断層撮影において回 転角度が小なるほど厚い層として投影され，層が厚けれ ば対照度は良く，薄け扎代恶くなる。しかし本撮影にお いては $50^{\circ}$ の時に良い影像を得た。 また断面フィルム間 距晟は装置の鄣す最小のものが最良であった。 
次ぎに複雑な檴造にて周团より取り国まれた㧢頭席桃 をX線写真に投影するには，頭蓋骨(骨組織)，咽頚㽍桃 (軟部組織)，奥咽腔（含気膑）これら三者のX線吸収度 に大きな差を有する側面加らの撮影がX線学的にも陰影 のコントラストの点で有効であることは自から知られ る。また頭部の正中に存在する咽頭扁桃の断層距離も簡 単に洪如易い，研究の結果においても側面像与なるら正

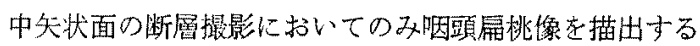
ことができ，前額面その他の斜面の場合は描写不能であ った，正中知状面のX線写真にお゙いて㸶磌屚桃の側面像 を正確に把握できるが，更に左右の状態を知るには 0.5 〜 1.0 cm 䧣った矢状面断層で知ることが可能である。乙

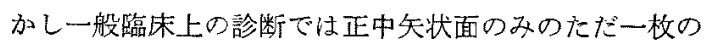
X線写真で充分である，摱影断尿方向儿関しては管球移 動方向に対して平行, 直角等種々の方向が考えられる。 断層撮影のX線装㽞は他部位の摱影が主として体韩に平 行に管球を移動して撮璟することが多いため, 撮影台が 管球移動方向に平行に長く置加九ている，それ故に本撮 影においても頭軸に平行にした方が撮影操作上好都合で あった，次にX線撮影は普通呼吸を停止せしめて行な う。これは呼吸による被写体の動摇をできるだけ少なく するためである。しかし本撮影に扔いては，呼吸を停止 せしをると軟口蓋が举上して舆胭腔を閒鎖することが多 く，接触あるいは接近した軟口蓋のため㸶頭局桃の輪郭

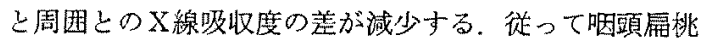
像が不鮮明となることが多い，而して閉ロして，安静奥 呼吸を行なわしめながら影影する必要がある。そ玌故に

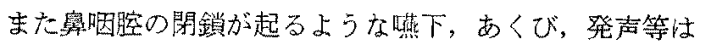

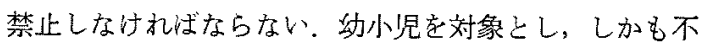
安定な頭部をX線撮影する場合，頭㥺の安定性と患者に 対して無理がなく，撮影時閒に㙂え得るような頭位並び に体位という事を念頭に置か秝ばならない，頭位は正中 矢状面の断阎撮影なるが故に摱影台に知状面走平行にし た頭位でこれはいかなる場合においても正確に保たれ ねばならない，この頭部の侧位に対して首および軀幹は 最も安楽存姿勢堂取らせた。これには頭部は右耳を下に して，頭軸㧍上び体軸をほぼ一致せしめた腹卧位を取ら せ，次いで左上半身を轻く起こし左手でこれを支える場 合が最良であった，首をあまり屈曲あるいは伸展すると 呼吸が苦しくなり不適当であった．頭部の固定は極めて 重要で，真の側位が少しでも崩れてしま5と㸶頭徧桃像 が不鮮明となる。側位は特に願部が撮影台に近かずく位 置に乱れ易い，それ故に臨部の沈下を防止するためにこ

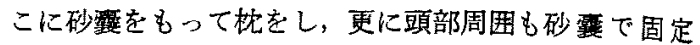
し，上部より圧追带を用いた。しかしこれらの固定にて は不充分であり，第 2 表の学童20名の撮影成績において

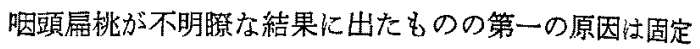
不充分による被写体の動摇と考えられる。これは撮影对 象が小児であるため，撮影開始と共に装嘿の動きや音に 警き頭部起動かしてしまうためである，それ故に撮影前 に断層撮影なるものの患者に対する不安在取り除くため 充分説明しておく必要がある，動摇による撮影失敗を避 けるための固定器の考案作製に関しては第 3 螎にて記述 寸る.

$$
\text { 5. 結語 }
$$

著者は東芝截面撮影装監A-2型( (孤移動式, 管球: 東芝 SDO-6-3 型，焦点 $\left(3 \times 3 \mathrm{~mm}^{2}\right)$ を用い，哂顗屚桃 をX線写真上に鮮明かつ的確に描写することができる諸 条件を研究し, 次の結果齐得た:

i) 撮影条件：管電圧 $75 \mathrm{kvp}$, 管電流 $40 \mathrm{~mA}$, 回転角 度 $50^{\circ}$, 璂射時間 2 秒, 焦点断面間距離 $100 \mathrm{~cm}$, 断面工 イルム間距雄18〜20cm.

ii) 撮影断層面: 頭部の正中矢状面.

iii）撮影断層方问：頭朝を管球移動方向に平行とし， 下腭骨切痕部を中心として頭頂より足部风移動。

iv）撮影頭位並びに体位：頭軸および体軸を管球移 動方向に一致せしめた腹卧位にて頭部の正中知状面を㩧

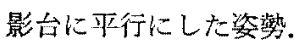

v) 撮影時呼吸：平常安静鼻呼吸.

\section{第 2 編 アデノトミ一前後の断層 $\mathrm{X}$ 線}

\section{像に関する研究}

1. 緒言

正中知面断尿撮影法が幼小㹸の胭頭扁桃の観察に極め て有用であることは第、編においてて述べたが，更に本撮 影法によるX線像が咽頭扁桃肥大度の判定にどれほど有 效であるがみるために，アデノトミー前後の断層X線 像と手術所見上童比較検討した。

2. 研究方法

藤枝市立志太総合病院耳蜜咽喉科外来勭れた患者の 中，咽頭扁桃肥大症，口盖屚桃肥大症，慢性扁桃资等々 診断された 5 才から12才までの男女36名定選び，Adenotomie あるいは Adenosonsillektomie 施行した。 Adenotom は La Force 氏扁桃腺刀中型むよび大型を使 用した．断層X線写真は手術前日あるいは手術当日の手 術前と手術後10〜14日とに撮影した，撮影装置おるび撮 影条件はすべて第 1 編と同様にした。 
第 6 図咽頭扁桃の断層 X線测定法（小泉法）
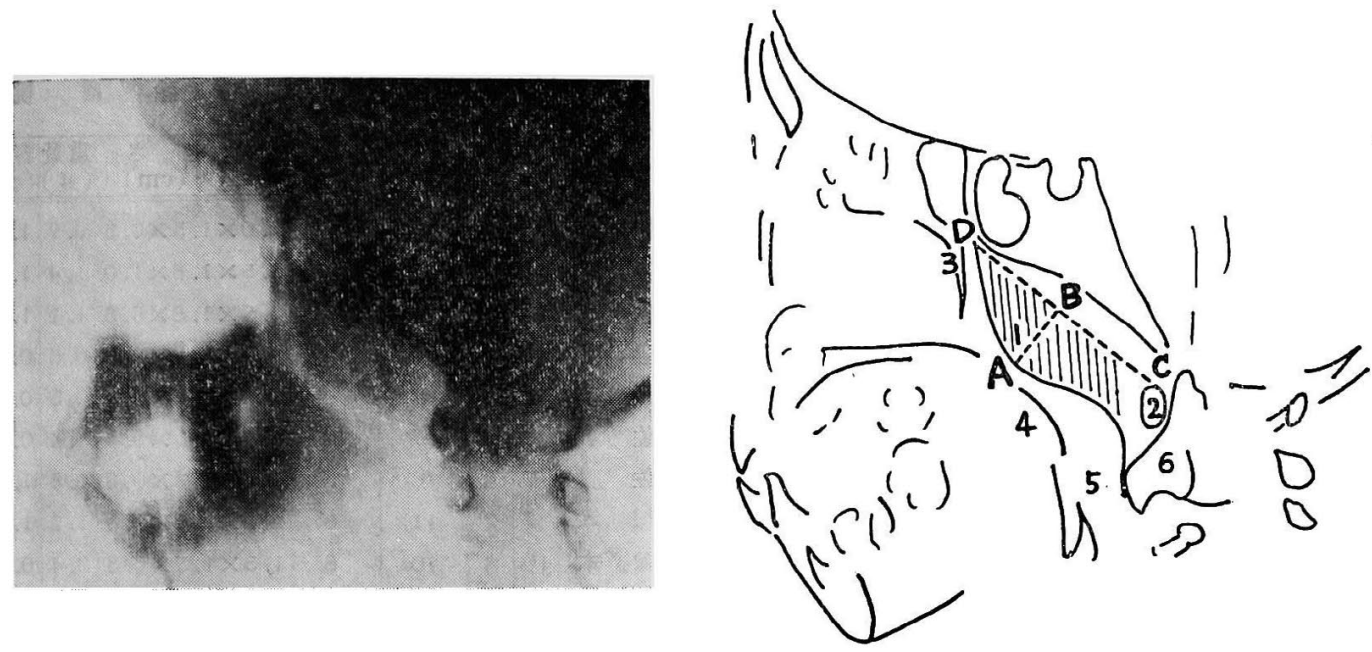
1. 咽頭扁桃
2. 環椎
3. 番咽頭满
4. 軟口蓋
5. 咽頭腔
6. 軸椎 $\mathrm{A}$-B
椎前結節前上縁一鼻咽頭灌上縁

咽頭扁桃肥大に対する X線的測定は小泉 ${ }^{221} に$ 準じ，第 6 図に示す如く咽頭扁桃の最大前後径を計測した. 寸な わち正中矢状面断層撮影法による咽頭扁桃X線像におい て, 咽頭扁桃の隆起の頂点 (A) より, 環椎前結節の前 上縁（C）と頭蓋底恖咽頭溝上縁 (D) を結ぶ直線 CD線上に下した垂線を $\mathrm{A}$ 一Bとした。この垂線 $\mathrm{A}$ 一 $\mathrm{B}$ を 咽頭扁桃のX線側面像における最大前後径とし，これに より咽頭扁桃肥大の程度を数值的に計測した. 切除扁桃 の容積は横田等 ${ }^{83}$ )に従い, 重量と共に手術後直ちに測定 した.

\section{3. 研究成 績}

5 才〜 12才までの男女36名のアデノトミー前役におう る断層X線像 (咽頭扁桃の最大前後径) の変化と切除扁 桃の大きさとの関係は第 4 表並びに第 7 図a）～c）に示 す如くである. すなわち切除された咽頭扁兆の重量並び に容量は夫々 $0.2 \sim 2.4 \mathrm{~g} ， 0.2 \sim 2.5 \mathrm{cc}$ であった. また手 術前後の断層X線像における最大前後径は夫々，6〜13 $\mathrm{mm}, 3 \sim 10 \mathrm{~mm}$ であった. 術前の最大前後径は何れも $6 \mathrm{~mm}$ 以上在示し, アデノトミー後の最大前後径は，ほ ぼ完全に切除されたと思われる症例では，切除扁桃の大 きさに拘らず何れも 6 ～ $7 \mathrm{~mm}$ 以下となっている. 術後 のX線像における最大前後径が $10 \mathrm{~mm}$ のもの 1 例, $8 \mathrm{~mm}$ のもの 4 例は何れも咽頭扁桃の上部が残存した不完全切 除例と考えられた．アデノミーによる鼻咽腔の変化はX
線写真上に正確にみることができた，更に臨床上口蓋扁 桃肥大のみで, 咽頭屎桃の肥大は無いと思われる 2 症例 について口蓋扁桃摘出術に際して実際に咽頭扁桃切除術 を施行した結果, 切除扁桃なく,この 2 症例の X線像最 大前後径は $5 \mathrm{~mm}$ および $3 \mathrm{~mm}$ であった. 以上38例の中 から 4 例を選びアデノトミ一前後のX線写真を示すと第 8 図a） d) の如くである.

術前のX線像における最大前後径と切除扁桃重量との 間では相関係数 $\mathrm{r}=0.57$ となり, 両者の間に有意なる相 関が認められた。しかし相関係数が 0.5 台に留まった理 由には，i）例数が36例と少なかったこと，ii）使用アデ ノトームが La Force 氏扁桃腺刀のみで，上部が残存し やすく, 不完全切除例が少数例にあったことの二つが考 えられた。

$\mathrm{X}$ 線写真における咽頭扁桃の最大前後径からその肥大 の状態を推測することができる．以上の成績から咽頭嵋 桃の肥大度をX線写真上より次の如く分類することがで きる. 寸なわちX線像における最大前後径が,

$5 \mathrm{~mm}$ 以下 : 臨床的肥大 (一)

$6 \sim 9 \mathrm{~mm}$ : 軽度肥大

$10 \sim 12 \mathrm{~mm}$ : 中等度肥大

13〜15mm：高度肥大

$16 \mathrm{~mm}$ 以上：著明肥大

咽頭扁桃の肥大度のこれらの分類を $\mathrm{X}$ 線写真について示 
第7图最大前後径の变化と切䟻届桃との関係

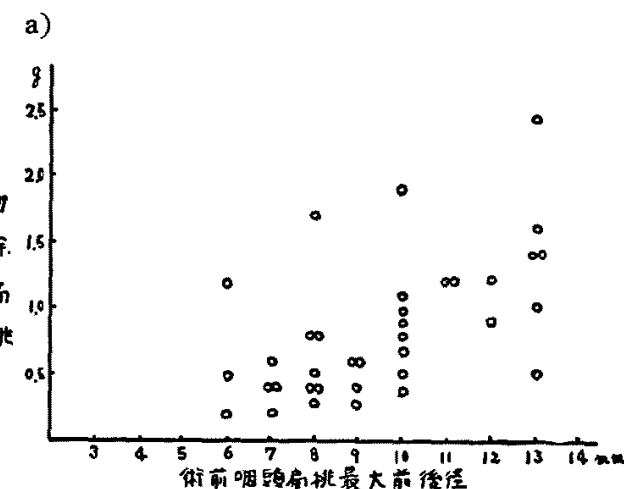

b)
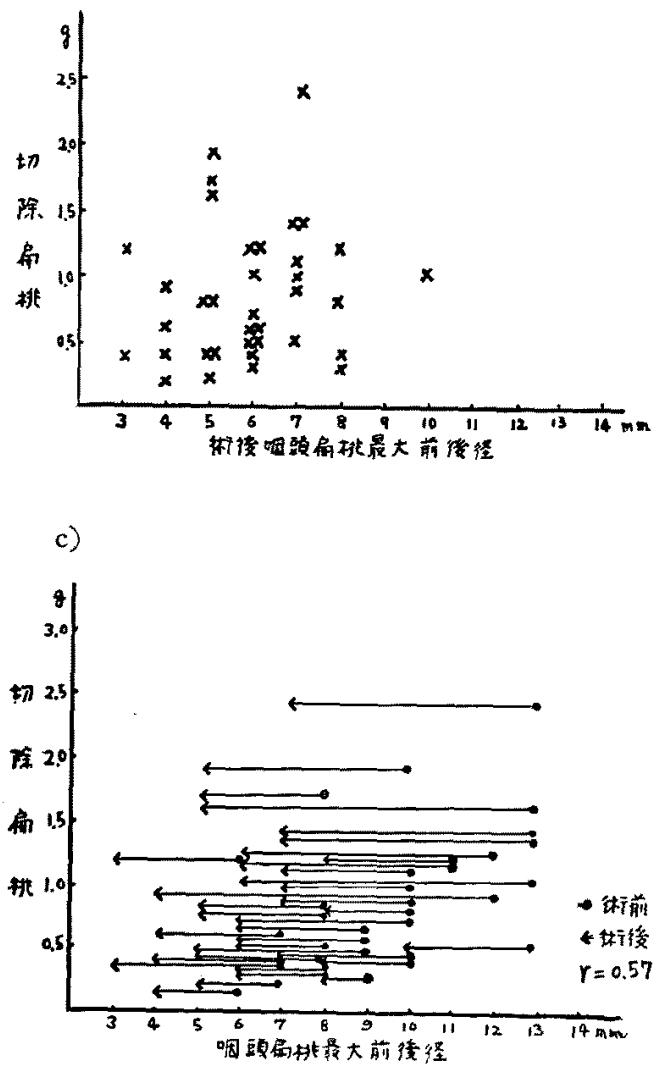

すと第9図a）〜e）の如くである.

4. 総括並びに考按

アデノトミー前後に坊けるX線学的観察は単純撮影法
第 4 表 アデノトミ一前後のX線像（最大前後徍） の变化と切除隔䄻との関係

\begin{tabular}{|c|c|c|c|c|c|c|c|c|c|}
\hline \multirow[t]{2}{*}{ No. } & \multirow[t]{2}{*}{ 氏 } & \multirow[t]{2}{*}{ 名 } & \multirow{2}{*}{$\begin{array}{l}\text { 年 } \\
\text { 合 }\end{array}$} & \multirow[t]{2}{*}{ 性 } & \multicolumn{2}{|c|}{ 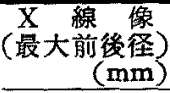 } & 切 & & 桃 \\
\hline & & & & & 術前 & 術後 & 大 है $\begin{array}{l}\text { 巳 } \\
(\mathrm{cm})\end{array}$ & (篗量 & $\begin{array}{l}\text { 容量 } \\
(c c)\end{array}$ \\
\hline 1 & 阔 & 崎 & 7 & $\hat{\delta}$ & 10 & 7 & $2.0 \times 1.5 \times 0.8$ & 0.9 & 1.0 \\
\hline 2 & 福 & 田 & 6 & $\delta$ & 13 & 7 & $2.5 \times 1.8 \times 1.0$ & 1.4 & 1.5 \\
\hline 3 & 䈏 & 根 & 7 & $\delta$ & 10 & 7 & $2.5 \times 1.8 \times 0.8$ & 1.1 & 1.1 \\
\hline 4 & 踩 & 葉 & 8 & $\hat{o}$ & 13 & 10 & $1.0 \times 1.5 \times 0.5$ & 0.5 & 0.4 \\
\hline 5 & $川$ & 崎 & 7 & q & 8 & 6 & $1.5 \times 1.5 \times 0.5$ & 0.5 & 0.5 \\
\hline 6 & 俈 & 贯 & 6 & q & 7 & 4 & $1.2 \times 1.2 \times 0.4$ & 0.4 & 0.3 \\
\hline 7 & 佐 & 貫 & 7 & ô & 8 & 5 & $2.0 \times 1.5 \times 0.8$ & 0.8 & 1.0 \\
\hline 8 & 塚 & 本 & 7 & 우 & 11 & 8 & $2.2 \times 2.0 \times 0.8$ & 1.2 & 1.2 \\
\hline 9 & 柲 & 本 & 10 & ô & 10 & 8 & $1.5 \times 1.5 \times 0.3$ & 0.4 & 0.5 \\
\hline 10 & 大 & 石 & 8 & $\hat{o}$ & 6 & 4 & $1.5 \times 1.0 \times 0.2$ & 0.2 & 0.2 \\
\hline 11 & 松 & 浦 & 8 & $q$ & 13 & 6 & $2.0 \times 1.8 \times 0.8$ & 1.0 & 1.1 \\
\hline 12 & 村 & 松 & 7 & $q$ & 8 & 6 & $1.2 \times 1.8 \times 0.6$ & 0.4 & 0.4 \\
\hline 13 & 大 & 橋 & 9 & $q$ & 7 & 3 & $1.4 \times 1.0 \times 0.4$ & 0.4 & 0.4 \\
\hline 14 & 長 & 圾 & 9 & s & 7 & 5 & 不 & 0.2 & 0.2 \\
\hline 15 & 增 & 日 & 9 & s & 12 & 4 & $2.0 \times 1.7 \times 0.6$ & 0.9 & 1.0 \\
\hline 16 & 粀 & 本 & 10 & $\hat{o}$ & 9 & 5 & 2. $0 \times 1.5 \times 0.3$ & 0.4 & 0.4 \\
\hline 17 & 近 & 藤 & 9 & 우 & 8 & 6 & $1.7 \times 1.5 \times 0.3$ & 0.3 & 0.3 \\
\hline 18 & 素 & 島 & 12 & $s$ & 11 & 6 & $2.0 \times 1.8 \times 0.6$ & 1.2 & 1.1 \\
\hline 19 & 青 & 島 & 11 & $q$ & 13 & 7 & $2.5 \times 2.0 \times 0.9$ & 2.4 & 2.5 \\
\hline 20 & 中 & 111 & 10 & $q$ & 8 & 5 & $1.7 \times 1.3 \times 0.3$ & 0.4 & 0.4 \\
\hline 21 & 池 & 上 & 7 & $q$ & 7 & 4 & $1.8 \times 1.5 \times 0.3$ & 0.6 & 0.7 \\
\hline 22 & 小 & 口 & 10 & $\$$ & 10 & 8 & $1.8 \times 1.5 \times 0.5$ & 0.8 & 0.8 \\
\hline 23 & 鍮 & 木 & 9 & 웅 & 10 & 6 & $2.0 \times 1.7 \times 0.5$ & 0.7 & 0.7 \\
\hline 24 & 松 & 浦 & 6 & $\delta$ & 9 & 6 & $1.8 \times 1.5 \times 0.3$ & 0.6 & 0.7 \\
\hline 25 & 平 & \# & 12 & $\hat{o}$ & 13 & 7 & $2.5 \times 2.0 \times 0.6$ & 1.4 & 1.5 \\
\hline 26 & 大 & 石 & 11 & $\hat{b}$ & 8 & 5 & $2.5 \times 2.5 \times 0.7$ & 1.7 & 1.7 \\
\hline 27 & 大 & 塚 & 9 & $\hat{o}$ & 10 & 5 & $3.5 \times 1.7 \times 0.8$ & 1.9 & 2.0 \\
\hline 28 & E & 科 & 8 & $q$ & 6 & 3 & $2.2 \times 1.8 \times 0.5$ & 1.2 & 1.1 \\
\hline 29 & 松 & 浦 & 9 & 우 & 8 & 5 & $1.9 \times 1.9 \times 0.4$ & 0.8 & 0.9 \\
\hline 30 & 桑 & 原 & 6 & $q$ & 12 & 6 & $2.0 \times 1.7 \times 0.6$ & 1.2 & 1.2 \\
\hline 31 & 清 & 水 & 6 & $\hat{\delta}$ & 9 & 8 & $1.5 \times 1.5 \times 0.3$ & 0.3 & 0.4 \\
\hline 32 & 河原 & 【崎 & 5 & $\hat{o}$ & 13 & 5 & $2.0 \times 2.0 \times 0.7$ & 1.6 & 1.5 \\
\hline 33 & 山 & 下 & 8 & 9 & 10 & 7 & $2.0 \times 1.5 \times 0.7$ & 1.0 & 1.0 \\
\hline 34 & 鈴 & 木 & 8 & q & 9 & 6 & $1.5 \times 1.2 \times 0.4$ & 0.6 & 0.6 \\
\hline 35 & 太 & 石 & 9 & $q$ & 6 & 6 & $1.8 \times 1.3 \times 0.2$ & 0.5 & 0.5 \\
\hline 36 & 紅 & 林 & 7 & o & 10 & 7 & $1.5 \times 1.3 \times 0.5$ & 0.5 & 0.5 \\
\hline
\end{tabular}

あるいは离電圧撮影法によりすでに Grandy2), Calth$\mathrm{rop}^{6)}, \mathrm{Weitz}{ }^{7}$, Z Ziefach"), 小泉 ${ }^{22)}$ 等により行なかれて おり，その重要性を指摘している，た胭頭扁挑肥大度 
第 8 図 フデノトミ一前後の変化

a）ほぼ完全切除例

術前

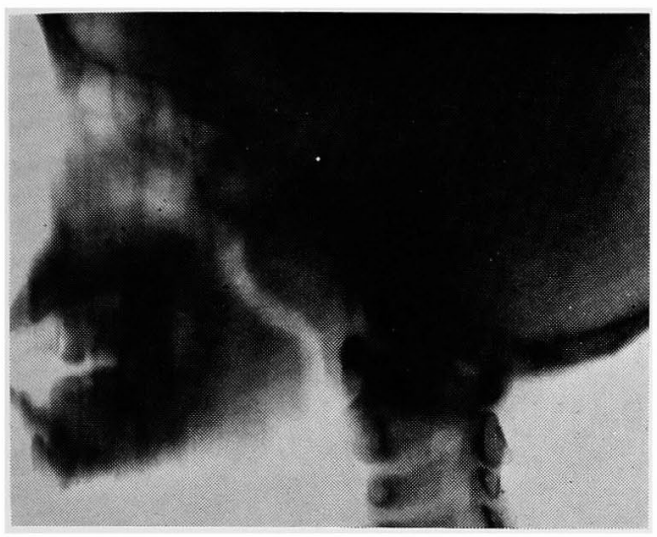

術後

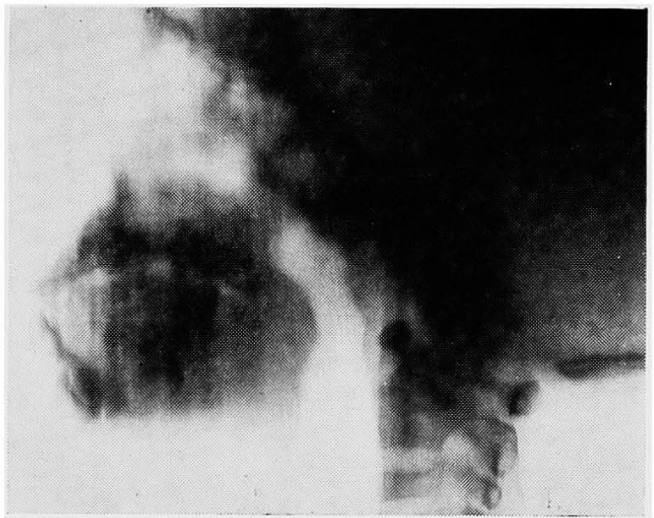

症例 15,9 才, 古, 切除扁桃 $2.0 \mathrm{~cm} \times 1.7 \mathrm{~cm} \times 0.6 \mathrm{~cm}, 0.9 \mathrm{~g}, 1.0 \mathrm{cc}$, 切除扁桃の大きさにほ ぼ一致した陰影欠損を認める。

b）不完全切除例

術前

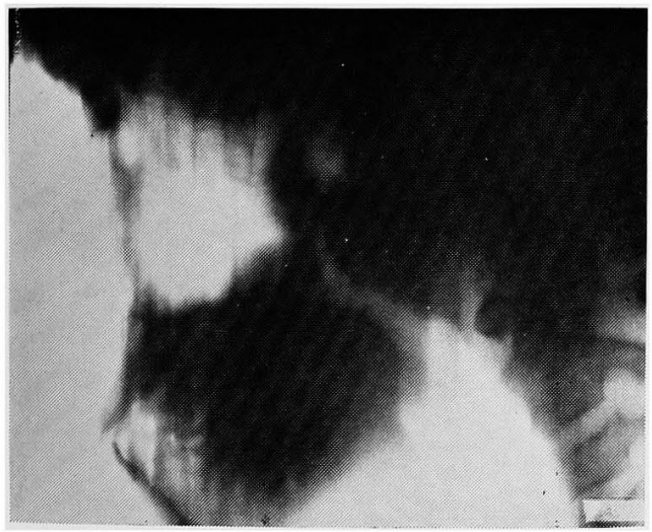

術後

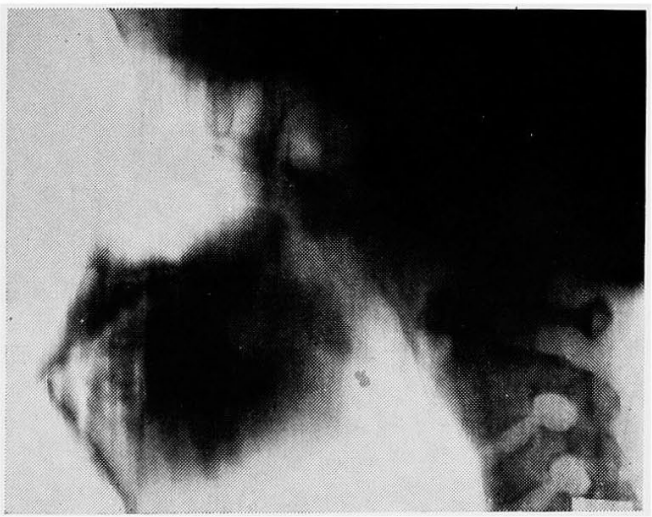

症例 19,14 才, 早, 切除扁跳 $2.5 \mathrm{~cm} \times 2.0 \mathrm{~cm} \times 0.9 \mathrm{~cm}, 2.4 \mathrm{~g}, 2.5 \mathrm{cc}$, 上部に扁桃残存. 
c) 肉身增殖例

術前

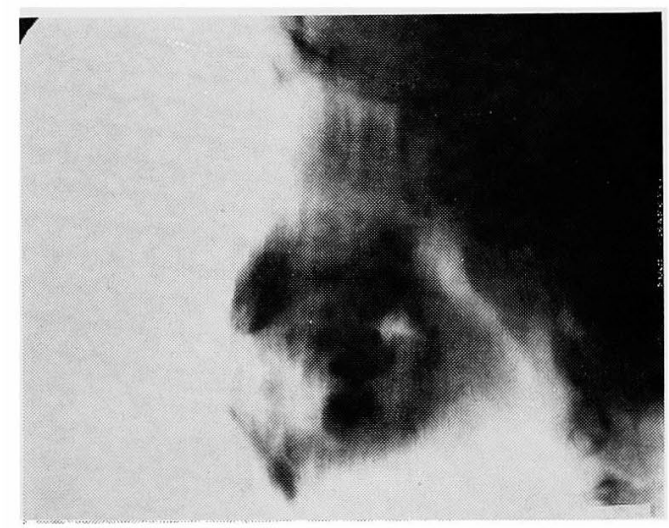

術後

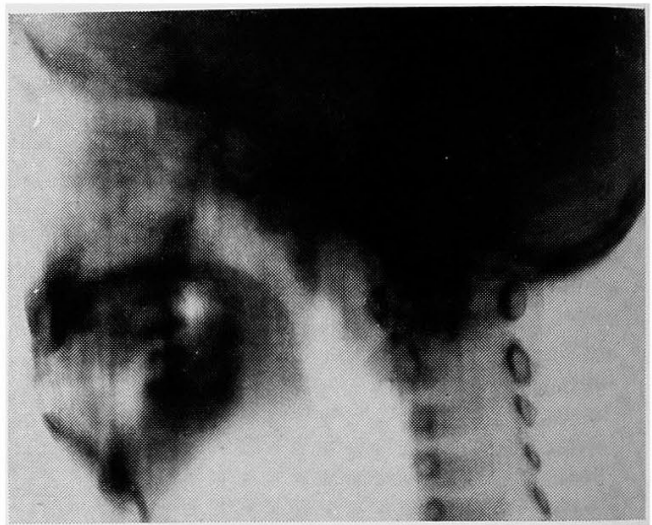

症例 3,7 才, 古, 切除扁桃 $2.5 \mathrm{~cm} \times 1.8 \mathrm{~cm} \times 0.8 \mathrm{~cm}, 1.1 \mathrm{~g}, 1.1 \mathrm{cc}$, 上下の扁桃切断面より 肉芽增殖.

d）臨床的扁桃肥大の無いと思われる例

術

前

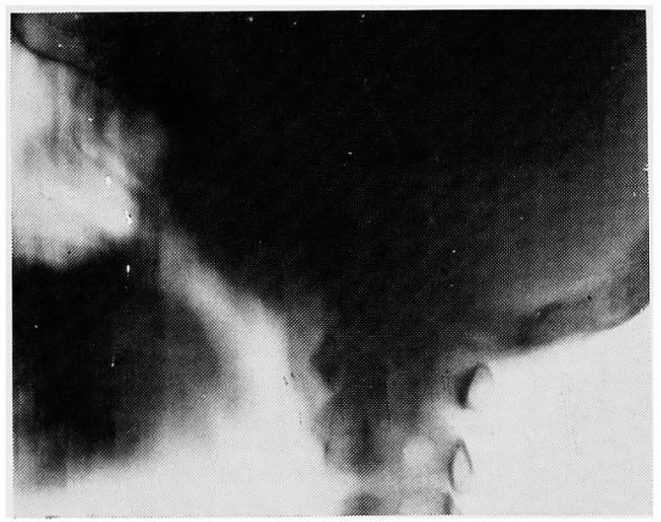

術後

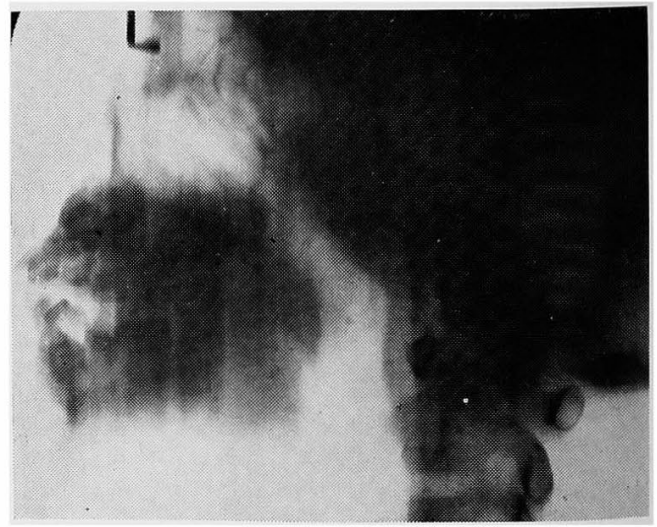

症例37, 9才, ô, 実際に切除術を施行するも切除扁桃なし. 
第9 図咽頭扁桃肥大度の分粸

a) 臨床的肥大 (一)

最大前後径 $3 \mathrm{~mm}$, 川村, 9 才, ㅇ

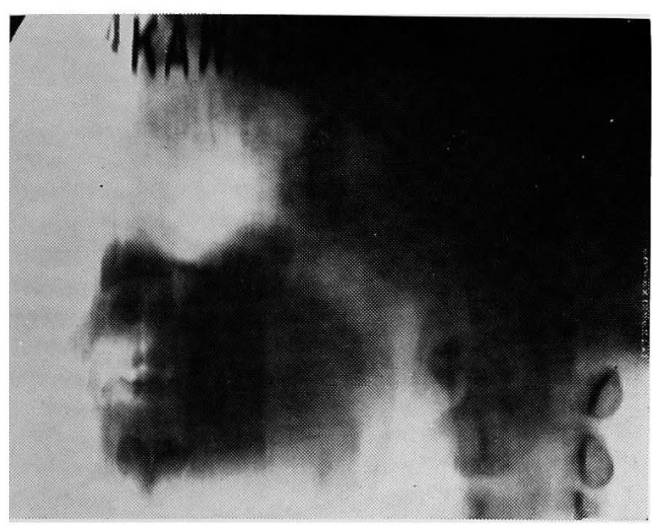

c）中等度肥大

最大前後径 $12 \mathrm{~mm}$, 河原崎, 5 才, 8

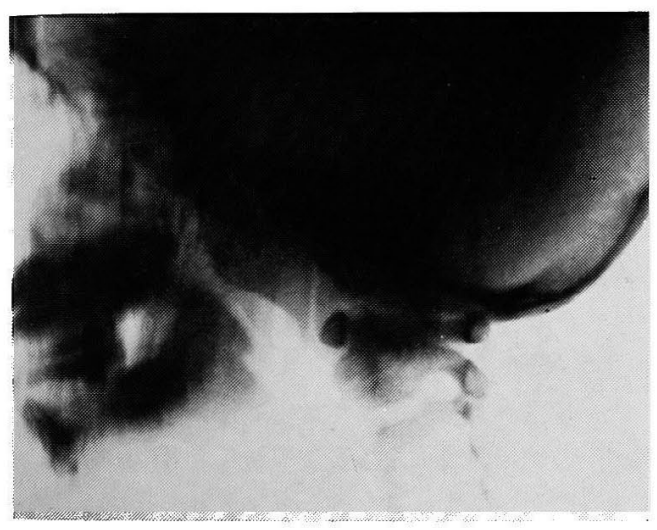

e）著明肥大

最大前後径 $16 \mathrm{~mm}$, 矢部, 2 才, $\delta$

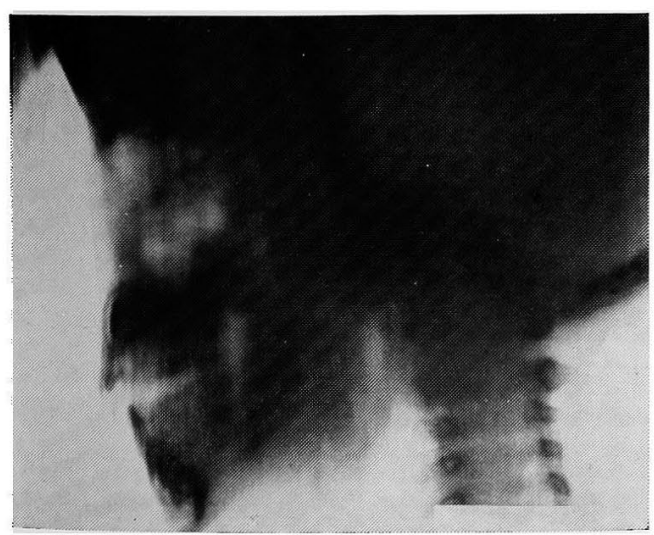

b）怪度肥大

最大前後径 $8 \mathrm{~mm}$, 松浦, 9 才, 9

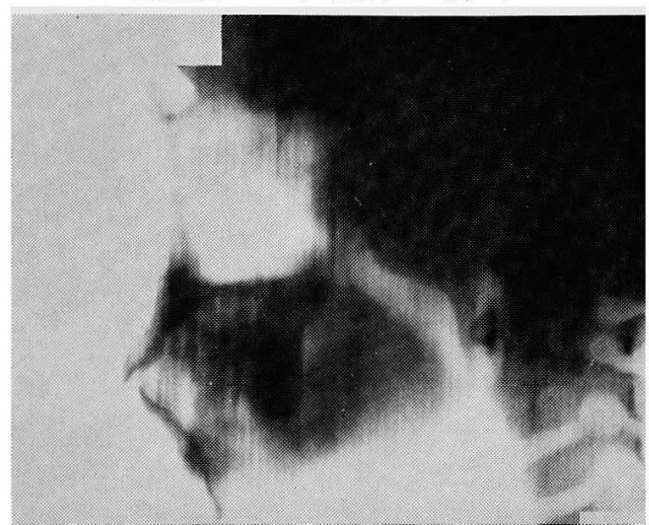

d）高度肥大

最大前後径 $14 \mathrm{~mm}$, 平井, 12 才, $\hat{\circ}$

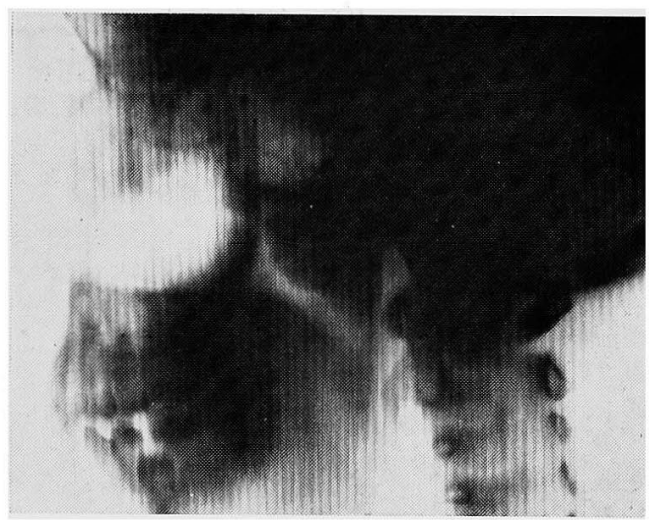


のX線的分類に関しては, Weitz ${ }^{7)}$, Bjuggren ${ }^{8)}$ 等は咽頭 扁桃か゚上咽頭天蓋より $6 \sim 7 \mathrm{~mm}$ 以上膨隆する場合を病 的肥大とし, $7 \sim 9 \mathrm{~mm}$ の厚さを最小肥大, $10 \sim 15 \mathrm{~mm}$ を中等度肥大， $15 \mathrm{~mm}$ 以上を著明肥大と分類した。 また 小泉 ${ }^{22}$ は咽頭扁桃の高電圧 X 線側面像における最大前後 径により, その最大前後径が $6 \mathrm{~mm}$ 以下のものと臨床的 肥大 (一) または軽度肥大, $7 \sim 10 \mathrm{~mm}$ を中等度肥大, 11〜15mm を高度肥大, $16 \mathrm{~mm}$ 以上を著明肥大とそれぞ れ 4 段階に分類した. 岩沢 ${ }^{28)}$ (1965) も小泉と同じ撮影 法の研究により, 小泉の分類が最も妥当であると述べ, 咽頭扁桃を $\mathrm{X}$ 線的に生理的肥大と病的肥大（または咽頭 扁桃肥大症）とに二大別した. すなわち小泉の分類によ る軽度肥大および中等度肥大を生理的肥大とし, 高度肥 大と著明肥大を呈した場合と著明なアデノイド症状を伴 う中等度肥大以上を示した場合にはいわゆる咽頭扁桃肥 大症 (アデノイド) と称すべきであると述べ, 病的肥大 を示寸場合にはアデノトミーの適応であると論じた.

Weitz の分類法あるいはアデノトミー前後のX線所見 と手術所見を基にした小泉の肥大度分類の成績は, 今回 著者が研究した断層撮影法による観察成績とほぼ一致し ており，臨床的に妥当なものと考えられる。

なおアデノトミー前後の鼻咽腔の変化は断層X線写真 上で常に明瞭にみることができ，またアデノトミー前の $\mathrm{X}$ 線像に㧍ける咽頭扁桃の最大前後径と切除扁桃の大き さとの間には平行性を認めることができた. このことは $\mathrm{X}$ 線写真より咽頭扁桃肥大の状態を推測することが可能 であり, 臨床上その意義は大であると考えられる.

幼小児における咽頭扁桃肥大の表現については, 従来 用いられているような視診, 触診等による方法では主観 が入り込む余地を有し, 数量的にこれを表現することは 困難であった. 今井 ${ }^{94)}$ (1952) は前鼻鏡検査により咽頭 啢桃の大きさの判定を行ない, 扁桃の下端が中鼾甲介下 端より上のものを肥大 $(-)$ とし, 以下下方におよぶに 従い肥大度が大として分類を試みた。後鼻鏡像において は, 一般に後鼻孔上縁に達するまでのものを軽度肥大, 後番孔の上半を覆ら程度のものを中等度肥大, 後鼻孔全 体を覆う程度のものを高度肥大という分類が行なわれて いる (3) 42) 46147). 一方また切除扁桃の容量あるいは重量の 如く，手術的侵撉により.肥大度を表現するものもある が85)，これはあくまでも切除された扁桃の大きさについ ての検討であった. 以上の諸点を考える時, 咽頭扁桃に 対寸る正中矢状面断層撮影法は, その前後径において咽 頭扁挑肥大の程度を正確に測定しうる.すなわち咽頭扁
桃肥大の確認は勿論のこと, 肥大度の判定のみならず, アデノトミーの際の指標としてあるいは術後の治療効果 の判定, 経過観察, 扁桃の再生状態等臨床的見地加極 めて利用価值の高い撮影法であると考えられる.

\section{5. 結 語}

手術前のX線像における咽頭扁桃の最大前後径と切除 扁桃の大きさとの間には平行関係が認められ，切除術に よる上咽頭の変化は $X$ 線写真上に極めて正確にみること ができる.これらのX線掞よび手術所見を基に咽頭扁桃 の肥大度の分類を試みた.

\section{第 3 編 頭部固定法に関する研究（頭 部 X線撮影固定器の試作）}

1. 緒言

咽頭扁桃の断層撮影研究において著者は最初頭部の固 定に砂砦および圧迫帯を使用した. しかしこの方法で は，本撮影が小児を対象とすることが多いためややもす ると固定が不充分で, 撮影時頭部が動摇移動することが あった.よって被写体の動摇を防ぎかつまた被写体の疲 労をも軽減し, 常に確実なX線写真を得るために頭部を 簡単な操作で正確完全に固定できるような頭部固定器を 考案試作した.

2. 研 究方法

現在 $\mathrm{X}$ 線撮影に利用されている固定用具について文献 的に調べ86) -981, これらの固定用具を参考にして, 本撮影 頭位 (正中矢状面を撮影台に平行にした頭位, 第 3 図) に適した固定器を種々考案, 作製し, 久点の改良に改良 を重ね，頭部を簡単にしてしかも確実に固定し得る固定 器を作製した. 更にこの固定器を使用して断層撮影を試 みた。

3. 研究成績

第 10 図試作固定器

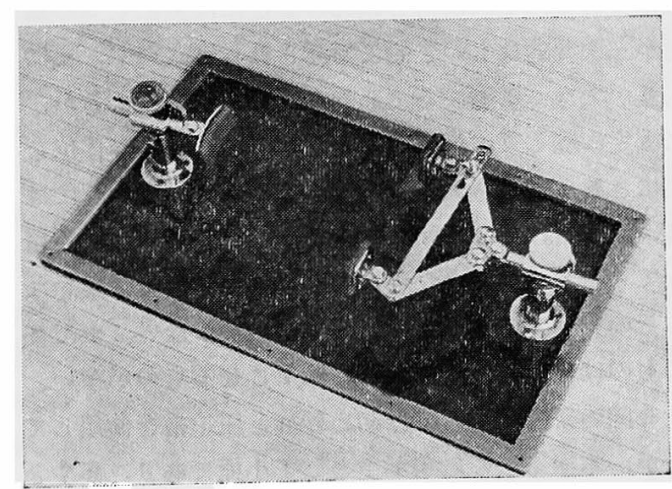


試作した固定器は第10図に示す如くである．周囲を金 属枠にて補强した合成樹脂の長方形基底板の両端に 2 本 の支柱を立て，これより腕をもって一方に 2 個，一方に は 1 個の固定端子を有与る。これらの固定端子は水平面
においてのみ自由に上下および開閉移動が可能であり， 被写体 (頭部) の大きさにより適宣の位置に移動固定で きるよらにしてある. 固定器の使用方法は第 1 編第 3 図 に示す姿勢において, 頭部を第11図に示すように固定器

第 11 図固定器の使用状沉

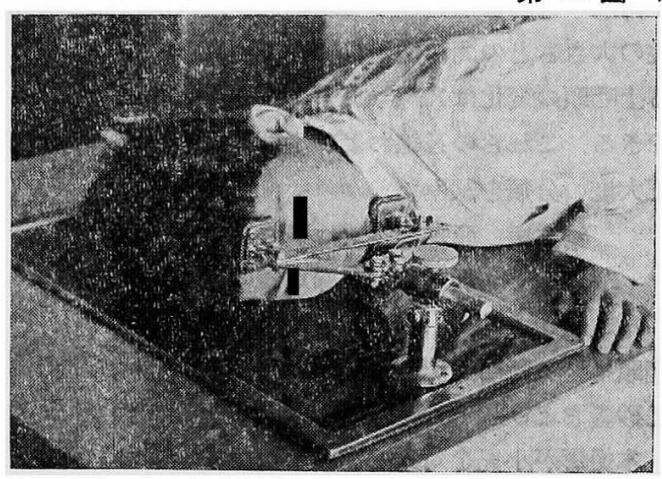

内に挿入する，頭部の大きさすなわち撮影台から正中 面までの高さや額虍間の距離により固定端子の位置を調 節し，しかる後に頭部を真の側位すなわち正中矢状面を 撮影台に平行にしてから, 前後より固定端子を狭めて, 額部, 頣部拉よび後頭部の三力所にて固定する. 固定器 使用後は被写体の動摇による撮影失敗はほとんど無くな り非常によい成績を得た。

\section{4. 総括並びに考按}

X線撮影 Positioning における用具特に固定用具の必 要性注今さらいうまでもない，近年X線診断学の向上並 びに諸器材の進歩にともない，撮影技術も自ずから高度 化が要求されている。これに対し撮影部位の固定の意義 には，i）像のボケの因子となる動摇を防ぐ，ii）被写体 の疲労を怪減する。iii）照射野の制限のため, iv) 被懪 量の減少の考虑等が举げられる。いずれも確実な像を得 るためである.これに対し頭部の固定には更に 3 つ基 本面が三次元的なものとして考虑されねばならず，更に 個人差が大きく影響するためその緩和が必要であるが， 更に固定に際しては患部の固定とともに，患者の体位を も楽にさせることも大切である。このため固定用具には 砂潞, 圧迫帯, Flexicast, Snow Block 等が一般に使用

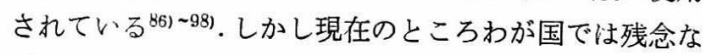
がらその方面での補助具の研究は極めて少ない．また従 来のものは操作が複雑で能率を低下させるものが多い. また今回の研究に当っては初的砂聂と圧迫帯を使用して いたが，本撮影法の対象が主として小児であり，多少と

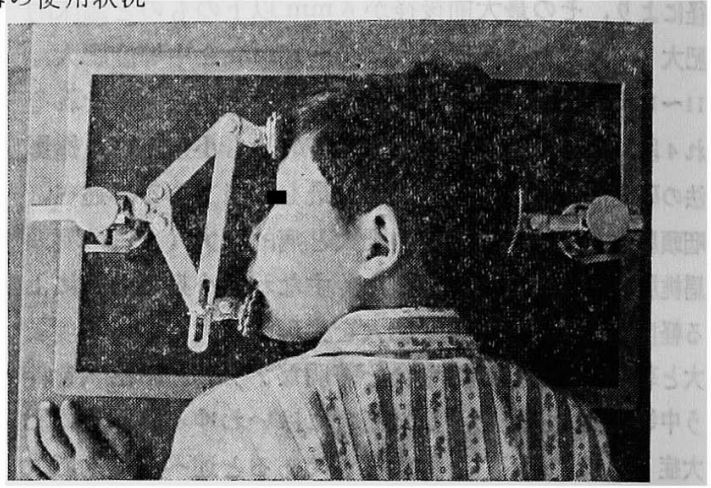

も笨屈な姿勢を取り，また断層撮影なるために撮影時間 が 2 秒と長いため, この砂整および圧迫帯による固定法 では不充分であり, 時に撮影時被写体が動摇して真の側 位が崩れてしまい, 正中矢状面の断層写真が得られず, 㸶頭扁桃を鮮明に描写することができないことがあっ た.この撮影失敗を防ぐ目的で幼小児といえども常に確. 実な X線写真を得ることを目的として上述の装置を製作 した.

なお本撮影において, 腹卧位にて頭部を側位にした場 合は頭位が不安定で, 第12図に示す如く側位が崩れ易

第 12 図
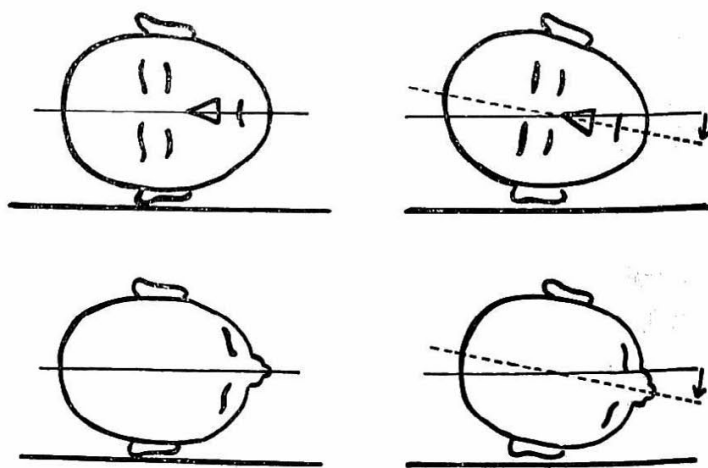

い，それ故に頣部の固定端子にはこれを防ぐために頋部 沈下防上板を取りつけた。（第13図）

この固定装置を用いることにより頭部を簡単にしかも 
第 13 図 沈下防止板

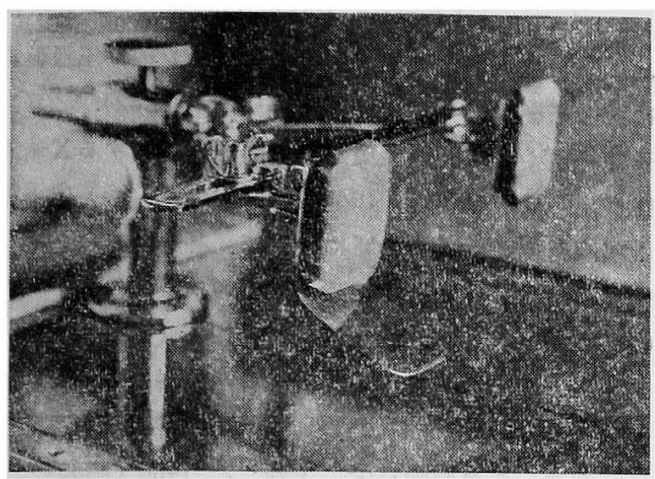

第 14 図 固定器の作り変え

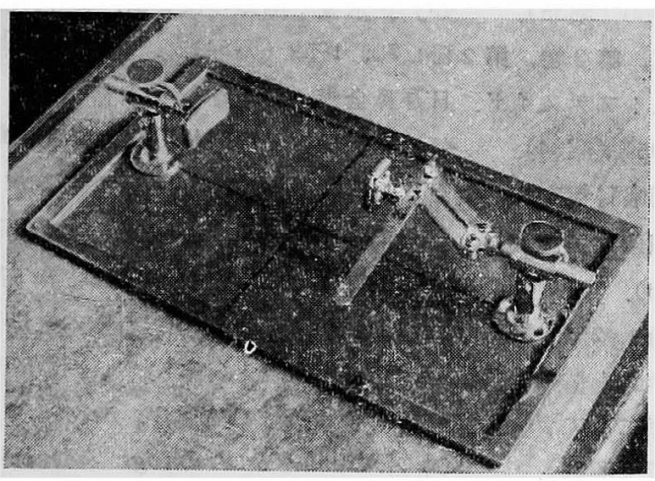

第 15 図 断層基準面測定器並びに定規

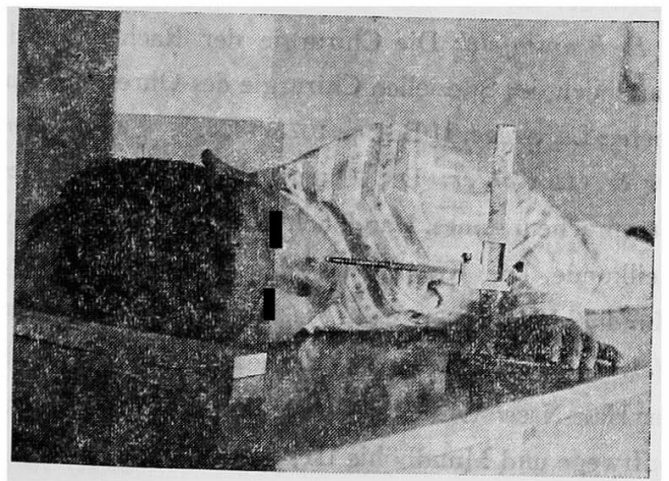

確実に固定し, 今まで時にみられた撮影失敗を避けるこ とができた. 更に従来行なわれていた人手による頭部固 定等を一切なくして, それら固定に従事した看護婦, 助 手の被懪を取り去ることができた.

また以上撮影に当っては, 必ずしも側位に限らず, 他 の頭位撮影にも広く利用可能である. 第14図の如く2 個
の端子を 1 個のものに作り変えることもできる．更に頭 部のX線写真については診断上基準面の正しい整位が極 めて重要である. このために色々の入射角指示具や角度 保持台等の補助具が考案されている99. 本撮影において も第15図に示すような断層基準面の測定器および定規と もいうべきものを自作し，これにより頭部が真の側位す なわち奥尖, 頃尖, 後頭結節等頭部固囲の数力所以上が 撮影台から同一高さになるようにして撮影した。

$$
\text { 5. 結語 }
$$

不安定な頭部のX線捍影においては撮影時被写体の動 摇により不満足なX線写真を得る。この撮影失敗を避け るために頭部固定器を考案作製した.

結諭

咽頭扁桃に対する正中矢状面断層撮影法は従来の諸種 診断法と相違し, 患者に何ら苦痛不快を与えることな く, 比較的容易かつ正確に実施することができ, 咽頭扁 桃疾患の診断, 経過観察, 記録等の一方法として臨床上 極めて有用で, 今後広く普及応用されるべきものであ る. なお本検査に対してはその勃果を高めるため一つの 頭部固定器を創案作製した。

\section{主要参考文献}

1) Migon, $M$.: Etude anatomo-clinique de l'appareil respiratoire par les rayons de Roentgen. Thèse. Paris 1898. Groth, K-E. 論文より引用. $\quad$ 2) Grandy, C. C.: Roentgenographic Demonstration of Adenoids. Am. J. Roentgenol., 14;114-115, $1925 . \quad 3)$ Schüller,: 戸塚 元吉諭文より引用. 4) Székács-Friedmenn, H.; Die röntgenologische Untersuchung der adenoiden Vegetation. Mschr. Ohrenheilk., 66; 1527-1536, 1932. Groth, K-E.: The Roentgen Picture of the Epipharynx of Childrn under Normal Conditions and by Adenoid Vegetations. Acta radiol., 14; 463-469, 1933. Calthrop, G. T.: Radiological demonstration of adenoids. Lancet, I; 1005, $1940 . \quad$ 7) Weitz, H. L.: Roentgenography of Adenoids. Radiology, 47; 66, 1946.

8) Bjuggren, G. et. al.: Occult Sinusitis in Children. Acta Oto-laryng., 42; 287, $1952 . \quad$ 9) Zwiefach, E.: The radiographic examination of the adenoid mass and upper air passages. J. Laryng. and Otology, 68; 758764, 1954. 10) Wilson, T. G.: Diseases of the Ear, Nose, and Throat in Children, p. 189, 1955.

Zuppinger, A. \& Rüedi, L.: Zur Darstellung des Sinus maxillaris, des Epipharynx und der Trachea mit Kon- 
trastmittel, Fortschritte auf dem Gebjete der Röntgenstrahlen. 49; Bd. 2, 176, 1934.12$)$ 大藤政三：咽 腔腪瘍のX線造影写真法について，ダレンッゲビート， $9 ; 590,1935$ (昭10). 13) Moulinard,j.: Intérét de la radiographie dans le diagnostic et le traitement des affections adénoidiennes. Ann. d'Oto-laryng., 66; 455464, 1949.14）神戸達二：咽頭扁桃のレ線診断。日 耳界，57;813，1954（昭29）。15）渡部三郎：所謂了 デノイド症状と鼻閉塞。日耳鼻，59；507，1956（昭31）。

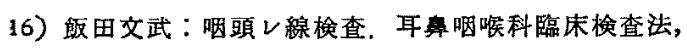
470,1959（昭34）. 17) 後藤敏郎：咽頭腔部のレ線 撮影法之診断. 耳咽晚科学, 上巻; 177, 1960 (昭35). 18）林四郎他：咽頭扁桃の間接撮影法. 社会保除医学猚 言, 3；25，1961（昭36）。19）潼野蜸一：咽喉頍鏡に よる鼻咽腔内視鏡検查法とX楾造影法について. 耳展, 5; 369，1962 (昭37). 20) Jing, B-S. and McGraw, $J$. P.: Contrast nasopharyngography in diagnosis of tumors. Arch. Otolaryg., 81；365, 1965. 21) 戸塚元 吉他: 咽頭扁挑疾患の高䉓王レントゲン診断法について. 日耳鼻，60；1395，1957（昭32）。22）小泉敏夫他： レ楾高压撮影飞よる咽頭扁桃の観察，(1)，(2)，(3)。耳喉 科，30;479，637，978，1958(昭33). 23) 滗户直 正: 初步者のための高䉓压撮影法, 特にフデ,イド撮影 への忘用。さくらX-レイ写真研究，14;9，1956（昭 31．24）菱山博交他：耳鼻科颃域の超高王撮影の試

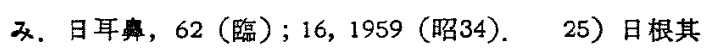
二：レ線高王撮影の経験. 日耳草，62；2298，1959(昭 34). 26) 伊藤英夫 : 咽頭扁桃のレ線学的研究，(1),

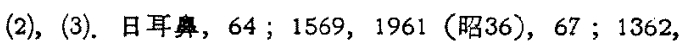

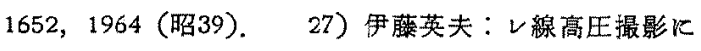
よる咽頭扁桃の観察. 日耳鼻，66；252，1963 (昭38). 28）岩讯武彦：咽頭扁桃に関する臨林的研究，(1). 耳と

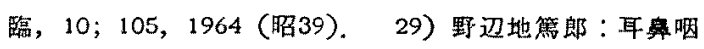
喉科頋域のX線壃断. 耳展, 8; 333, 1965 (昭40).

30）梅野正義：高匢レ線咉画に上る棓音発声特の軟口蓄 並びに舌根部運動に関す西研究。耳卧，55；305，19 62 (昭37). 31) Grossman, G.: Tomographie I. For tsch. Röntgenstrahlen, 51；61, 1935. 32) 三島則 美：聴器の断層レ線学的研究、日耳聴，62；2505，1959 （昭34）. 33）寺田勝光：断層レ線撮影に上る鼻中隔

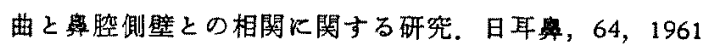
(昭36).34) 日比野勉：日本語粠音関するX缐的研 梦, (1)，(2)，(3). 大阪大学医学雑読，1；189，1956（昭
31). 36) Epstein, B. S.: Laminagraphy in diagnosis of nasopharyngeal tumors. Radiology, 56; 355-362, 19 $51 ， 36 ）$ 高須賀信夫他：上咽頭腫蕩のレ楾高王撮影並 びに断周撮影。月耳鼻，60；987，1957（昭32）。37)

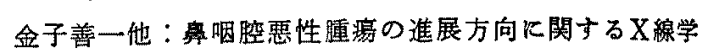
的観察. 耳展，5；211，1962 (昭37). 38) 山下憲 治：咽頭扁桃肥大症の診断について，耳莮蹦，47; 651， 1954 (昭29), 39) 河田政一：咽頭検查法。臨床耳 咽喉科全書, 第 3 巻, 第 1 册；97，1965（昭40）。 40) 久保隆一：咽頭扁桃肥大，臨床耳鼻咽咚科全書，第 3 巻,

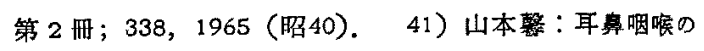
一般診察法. 耳悬咽唉科学, 上巻; 7, 1960 (昭35).

42) 岩本应之丞：扁桃疾患.耳鼻咽喉科学, 下巻; 1101, 1960 (昭35)。43）立木豊：咽頭の検査法。日耳禹全 書, 第 3 巻, 第 2 冊; 70, 1959 (昭34)。44) 鳥居恵 二:アデノイド.日耳舞全書, 第 3 巻, 第 2 冊; 135 , 1959 (昭34).45) 野坂保次：咽頭検亘法。臨床耳臬 咽喉科険查法, p. 371，1965（昭40）. 46）白岩俊雄：

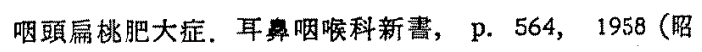

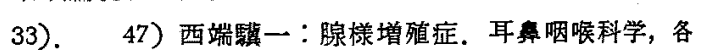
䧻；429，1942(昭17).48) 鈴木篤郎：フデノイドの， 診断. 俉州医学雑誌, $1 ; ; 81,1952$ (昭27). 49) 鳥居 恵二：フデノイド特にその診断。日本臨床， $5 ； 498$, 19 47 (昭22). 50) A. Denker \& Brünings: Adenoide Vegetation. Lehrbuch der Krankheiten des Ohres und Luftwege, 8u. 9 Auflage; p. 378, 1923. 51) L. Katz \& F. Blumenfeld: Die Chirurgie der Rachenmandel, Handbuch der Speziellen Chirurgie des Ohres und der oberen Luftwege, II Bd.; p. 1073, $1925 . \quad$ 52) A. Denker \& $O$. Kahler: Die Untersuchungsmethoden des Nasenrachenraumes. Handbuch der Hals-Nasen-OhrenHeilkunde, Die Krankheiten der Luftwege und der Mundhöhle I; 248, 1925. 53) A. Denker \& O. Kahler: Die Hyperplasie der Rachenmandel. Handbuch der Hals-Nasen-Ohren-Heikunde, Die Krankheiten der Luftwege und Mundhöhie III; 129, 1928.

Francis, L. Lederer: Anatomy of Pharynx. Diseases of the Ear Nose and Throat, IV Ed.; 483, 1945. Ballenger, W. L. \& Ballenger. M. C.: Chronic hyperplastic adenoid. Diseases of the Nose Throat and Ear, 10th Ed., p. 294, $1957 . \quad$ 56) Edward Pernkopf: Topographische Anatomie des Menschen, IV Bd. I Hälfte, 1957. 57) G. M. Coates, H. P. Schenck, M. V. Mil- 
ler: Acute and Chronic Inflamatory Diseases of the Nasopharynx. Otolaryngology, Chapter 7, vol. IV; 78, 1960. 58）川崎達矢：アデノイドの大きさと切除術に ついて. 耳喉科，31；545，1959(昭34).59) 後滕钽 郎：レントゲン検査法, 耳鼻咽缶学, 上巻；141，1960 （昭35），60）後藤光治, 末広惠三：咽頭並びに喉頭科レ

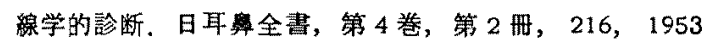

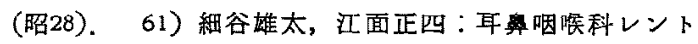
ゲン䒨断及治滰, 1931（昭 6)。62）横井勝朗, 福田 拣：人体X線撮影法（上，中，下)，1964（昭39）。

63) 高橋停次：X線撮影の検查々手びき, 1966 (昭41).

64) 践田政雄：图説骨X線撮影法, 1966 (昭41).

入江英雍：レントゲン检查法（その運び方と考え方）, 1966 (昭41). 66) 御園生圭輔，江藤元樹：X缐写真 の撮り方と現像処理，1965（昭40）. 67）古賀良彦, 入正英蜼: 故射線診断学 ( $1 \sim 6$ 巻)，1967 (昭 42).

68) 由宮知恥夫：レントゲン鄁断学入門，1965 (昭40).

69) 田坂皓：X線による診断。放射線医学, p. 967, 19 59 (昭34)，70）本城明朗：耳鼻咽喉科レ線猃断の要

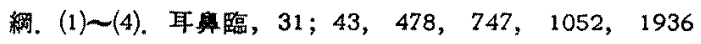
(昭11)，71）深津久治：耳科領域に出けるX線撮影

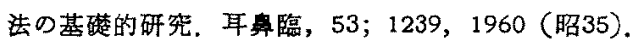

72）渡理正英他：X楾撮影技衡の時間(総論)，写真々技

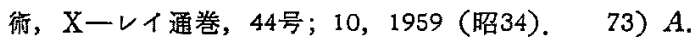
Denker \& $O$. Kahler: Röntgenuntersuchung der Nase und Nasenhöhlen. Handbuch der Hals-Nasen-OhrenHeilkunde, Die Krankheiten der Luftwege und der Mundhöhle I; 953, 1925. 74) A. A. de Lorimier, $H$. G. Moehring, J. R. Hannan: Climical Roentgenology, vol. II; 352, 1954.75$)$ 松川1明：断㬝撮影。臨床耳 咽焐科梌查法, 344，1965（昭40）。76）松川明：断 層撮影法の進步と臨床への応用。略療，15；612，1962 (昭37)，27）中村実他：耳算科項域の断㬝搌影法。さ くらX-レイ写真研究, 12巻, 3号；1，1961 (昭36).

78）草皆太平：断图撮影法の研究. 日放技, $17 ; 143$, 1961 (昭36)。 79) Boczoñ, S.: Möglichkeiten der Tomographie in der Otolaryngogie. Zent-blatt of H-NO., 48; 143, 1953. 80) Epstein, B.S.: Skull laminagra phy. Radiology, 38; 22-29, 1942. 81) Holvey, E. H. et. al.: Tomography of the Skull. Radiology, 44; 425448,1945. 82) 三島則美他：断層撮影に上る咽頭扁桃の 観察。日耳鼻，66；254，1963(昭38)。 83) 横田和夫 他：咽頭扁桃の組織像と通気障碍。耳鼻臨，47；366, 2954
(昭29)、84) 今井三郎：アデノイドを中心とした学童

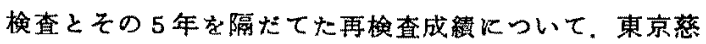
恵会医科大学雑誌，67；370，1952（昭27）８5）餃島 千秋：アテノイトの大きをとアデノトミ前後の聴力につ いて，日耳最，66；1445，1963（昭38）。86）松本宗 夫 : 頭部撮影固定補助具. 第22回日放技学会総会抄録集, p. 87，1966（昭41）。 87）加藤芳郎他：脳血管撮影用

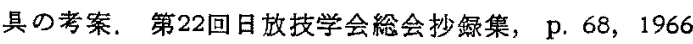
(昭41). 88) 林周二他：撮影用固定具の考案. 第22回 日故技学会総会抄録集，p. 69，1966（昭41）。 89）松 田憲司：頭部固定台。日放技，22；76，1966(昭41). 90) 中村実他：X線撮影㭪助具の試作。日放技，21；18, 1965 (昭40).91) 花本実穂他：急患頭部単純撮影及 び脳血管撮影器の一考案。日放技，21；105，1965(昭 40). 92) 仲田武：撮影台の試作について。放技, $21 ; 310 ， 1965($ 昭40).93）岡崎長：X線写真撮影補 助具について。日放技，21；311，1965（昭40）。 94） 林周二他：撮影用固定具の㮩討。日放技，21；316，1965 (昭40).95）林周二他：頭部の固定器についての考案 と試作。日放技，21；317，1965（昭40）,96）林周二 他：撮影用固定具飞対する二三の考案と試作. 日放技, $21 ； 379 ， 1965$ (昭40). 97) 遠藤朗: 撮影補助具の一 っとして，写真と技術，X一レイ通巻，46号；6，1959 (昭34). 98) 中村実他：X線撮影に利用される撮影

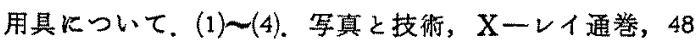
号；17，1960 (昭35)，52号；10，1961 (昭36)，56号; 1,1962 (昭37)，59号；31，1962（昭37）.

稿を終るに臨み，終始御懇切なる御指導，御 校閲を睗った耳筆咽啹科学教室柏戸貞一教授主 び放射楾科学教室伊東乙正教授に梁謝の意を 表すると共に，本研究に際して，種々御指導， 御援助をいたたいた本学耳咽喉科学教室講師 三島則美博士（藤枝市立志太総合病院耳鼻咽喉 科医長)，並び教空員各位，生藤枝市立志 太総合病院ヶ長, 二階堂忽四郎博士並びに同病 院放射線技師各位に対してる心から感謝の意を 表します。

な括本論文の要旨は，第64回日本耳界咽喉科 学会総会，闻菓地方会第 387 回例会及び第 412 回例会並び第6 回神奈川医学会総会に和いて 発表した。

（原稿到着 昭和 42.6.8 日） 